\title{
Ten questions about radiant heating and cooling systems
}

\author{
Rhee, Kyu-Nam; Olesen, Bjarne W.; Kim, Kwang Woo
}

Published in:

Building and Environment

Link to article, DOI:

10.1016/j.buildenv.2016.11.030

Publication date:

2017

Document Version

Publisher's PDF, also known as Version of record

Link back to DTU Orbit

\section{Citation (APA):}

Rhee, K-N., Olesen, B. W., \& Kim, K. W. (2017). Ten questions about radiant heating and cooling systems. Building and Environment, 112, 367-381. https://doi.org/10.1016/j.buildenv.2016.11.030

\section{General rights}

Copyright and moral rights for the publications made accessible in the public portal are retained by the authors and/or other copyright owners and it is a condition of accessing publications that users recognise and abide by the legal requirements associated with these rights.

- Users may download and print one copy of any publication from the public portal for the purpose of private study or research.

- You may not further distribute the material or use it for any profit-making activity or commercial gain

- You may freely distribute the URL identifying the publication in the public portal 
10 Questions

\title{
Ten questions about radiant heating and cooling systems
}

\author{
Kyu-Nam Rhee ${ }^{a, 1}$, Bjarne W. Olesen ${ }^{\text {b, } 2}$, Kwang Woo Kim ${ }^{\text {c, * }}$ \\ a Department of Architectural Engineering, College of Engineering, Pukyong National University, Republic of Korea \\ ${ }^{\mathrm{b}}$ International Centre for Indoor Environment and Energy, Department of Civil Engineering, Technical University of Denmark, Denmark \\ ${ }^{c}$ Department of Architecture and Architectural Engineering, College of Engineering, Seoul National University, Republic of Korea
}

\section{A R T I C L E I N F O}

\section{Article history:}

Received 24 September 2016

Received in revised form

15 November 2016

Accepted 15 November 2016

Available online 16 November 2016

\section{Keywords:}

Radiant heating and cooling system

Thermal comfort

Heat transfer

Energy simulation

Control

\begin{abstract}
A B S T R A C T
Radiant heating and cooling (RHC) systems are being increasingly applied not only in residential but also in non-residential buildings such as commercial buildings, education facilities, and even large scale buildings such as airport terminals. Furthermore, with the combined ventilation system used to handle latent load, the radiant cooling system has proven applicable in hot and humid climates. It is well known that the RHC system has advantages of low draught risk, quiet operation, low energy consumption, and ability for design integration with building elements. These merits have motivated numerous studies on RHC systems in terms of comfort, heat transfer analysis, energy simulation, control strategy, system configurations and so on. Many studies have demonstrated that the RHC system is a good solution to improve indoor environmental quality while reducing building energy consumption for heating and cooling. On the other hand, the RHC system has limitations such as complicated control of Thermally Activated Building System (TABS), acoustical issues, higher capital cost and cooling load than conventional air systems, and so on. For now, the required mitigation of these limitations and the need to extend the applicability of the RHC system are providing the continuous impetus for research on RHC systems. This paper summarizes the important issues involved in the research on RHC system, whereby ten questions and answers concerning the RHC system are discussed, which will help researchers to conduct relevant studies.
\end{abstract}

(c) 2016 Elsevier Ltd. All rights reserved.

\section{Introduction}

Archeological studies have revealed that the radiant heating system can be traced back to ancient Asia (Chinese kang and Korean ondol) and Europe (Roman hypocaust) [1-3]. In the early development of the system, it was mostly operated via hot flue gases passing through the underfloor space. Since polyethylene was adopted as a piping material in the early 20th century, the application of water-based (hydronic) radiant heating systems began to increase in Europe [4]. The radiant cooling system has proved to be successful if used in conjunction with a ventilation system [4].

Recently, radiant heating and cooling (RHC) systems have been widely applied not only in residential but also in non-residential

\footnotetext{
* Corresponding author. 39-428, Department of Architecture and Architectural Engineering, 1 Gwanak-ro, Gwanak-gu, Seoul, 08826, Republic of Korea.

E-mail addresses: knrhee@pknu.ac.kr (K.-N. Rhee), bwo@byg.dtu.dk (B.W. Olesen), snukkw@snu.ac.kr (K.W. Kim).

1 Department of Architectural Engineering, 45 Yongso-ro, Nam-gu, Busan, 48513, Republic of Korea.

2 Nils Koppels Allé, Building 402, 2800, Kgs. Lyngby, Denmark.
}

buildings such as office buildings, retail stores, schools, and even large scale buildings such as airport terminals, railway stations, etc. Radiant floor heating systems are installed in almost all residential buildings in Korea [1] and 85\% of rural houses in northern China [3]. It has been reported that $30 \%-50 \%$ of new residential buildings in Germany, Austria and Denmark are equipped with a radiant floor heating system [5], while its application has been extended to cooling purposes in mild climates such as Europe and North America. Furthermore, with the combination of a ventilation system to handle latent load, the radiant cooling system has proven to be feasible in hot and humid climates such as China, Thailand, Singapore, India, etc.

In contrast to conventional heating and cooling systems, the RHC system operates based on three heat transfer modes in order to provide necessary thermal capacity. Additionally, it needs to be supplemented with a ventilation system because radiant systems basically only deal with sensible load. In particular, the radiant cooling system should be designed to prevent condensation on radiant surfaces as mentioned earlier. These characteristics may make it difficult to design, install, and control the RHC system. 
Nonetheless, applications of the RHC system have been steadily increasing because of its high thermal comfort level, quiet operation, energy saving potential, integration with building design, and so on.

These merits have motivated numerous studies on the RHC system in terms of comfort, heat transfer analysis, energy simulation, control strategy, and system configurations, which have contributed to the establishment of fundamental theory and to practical applications of RHC systems. The requirement to improve the performance and extend the applicability of the RHC system is providing continuous impetus for research on RHC systems. This paper summarizes the important issues on the research of the RHC system, whereby ten questions and answers concerning the RHC system are discussed, which will help researchers to conduct relevant studies.

\section{Ten questions and answers}

\subsection{General}

\section{1) What is the definition of the radiant heating and cooling (RHC) system?}

In general, the RHC system is defined as a system in which radiant heat transfer covers more than $50 \%$ of heat exchange with a conditioned space [6]. Compared to all-air systems which depend on convection only, the RHC system provides heating and cooling by the combination of radiation and convection in a building $[7,8]$. Depending on the position of the piping in the building, the RHC system is usually classified into either (i) embedded surface systems (pipes placed within a building layer (floor, wall, ceiling) which is isolated from the main building structure: Fig. 1(a) $[9,10])$, (ii) thermally activated building system (pipes integrated into main building structure (ceiling, wall, floor): Fig. 1(b) [9,10]), or (iii) radiant panel system (pipes integrated into light-weight panels: Fig. 1(c) $[6,9]$ ). For heating, it is also possible to use electric cables instead of pipes.

\section{2) What are the international standards or guidelines on the design, installation, and control of the RHC system?}

Various technical guidelines have been published to provide design criteria, thermal capacity calculation, and dimensioning of the RHC system [6,7,9] Recently, ISO/TC 205 has developed a comprehensive set of international standards (ISO 11855 parts 1 to 6 ) that specify comfort criteria [12], determination of heating and cooling capacity [10,13], design and dimensioning [14], installation [15] and control [16] of the RHC system.

ISO 11855 can be applied to an embedded surface system and thermally activated building system (TABS) which are integrated into the wall, floor, or ceiling without any open air gap [17]. For a testing method, EN 1264-5 defines the determination method of the heating capacity of the wall and ceiling heating surfaces, and the cooling capacity of the wall, ceiling and floor cooling systems [18].

Standards for hydronic radiant heating and cooling panel systems are currently being developed [19] (ISO 18566 series), which will include technical requirements, determination of heating/cooling capacity, design, and control of ceiling mounted radiant panels. Test methods of cooling capacity for the radiant panel system are specified in EN 14240 [20] and ANSI/ASHRAE 138 [21].

For technical guidelines, the ASHRAE handbook [6] deals with principles of radiant systems, heat transfer calculation, general design consideration, electrically heated radiant systems, design procedure, and controls. The REHVA guidebook [9] includes system types, heating/cooling capacity, control, operations, and installation of low temperature heating and high temperature cooling systems. A recent guideline for the TABS provides information on the design, commissioning, operation, and control of GEOTABS, which is a geothermal heat pump combined with a thermally activated building system [22].

\subsection{Comfort}

\section{3) What are the advantages of RHC systems in terms of thermal comfort compared to conventional air systems?}

By utilizing the radiant heat transfer between the human body and radiant surfaces, a radiant heating system can achieve the same level of thermal comfort at a lower air temperature and a radiant cooling system can provide the equivalent thermal comfort at a higher air temperature [8,9]. Due to the small temperature differences between a heated or cooled surface and the occupied space, the RHC system can benefit from the self-regulating effect, which can provide a stable thermal environment to the occupants within the space [23].

In addition, the RHC system can provide an ideal vertical air temperature gradient $[5,24,25]$ as shown in Fig. 2 and mitigate cold draught due to excessive air movement [26-28], because it operates using significantly less air flow compared to conventional air systems. Corgnati et al. showed that a chilled ceiling combined with mechanical ventilation can significantly decrease the draught risks by reducing the vertical drop of an air jet, which is often observed in all-air systems [26]. Hao et al. claimed that a chilled ceiling with displacement ventilation could not result in draught risk, if the heat removal by the chilled ceiling is less than $100 \mathrm{~W} / \mathrm{m}^{2}$ [27]. Objective

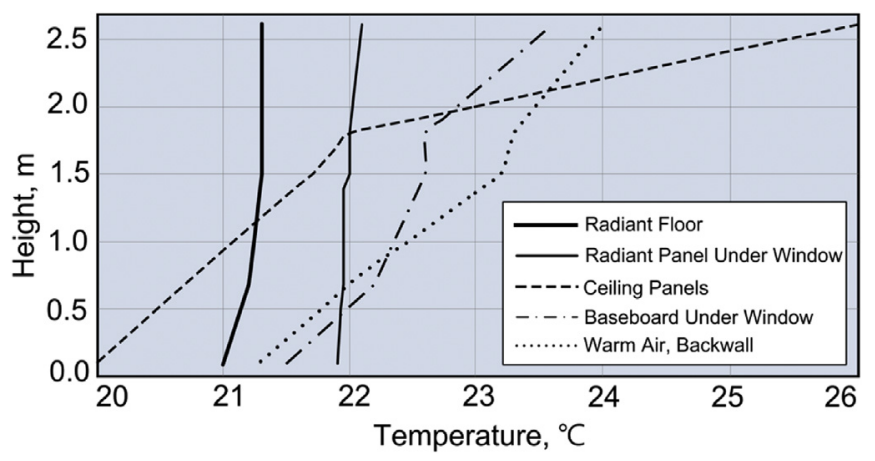

Fig. 2. Vertical air temperature differences measured in a test space for different heating systems (based on Ref. [5]).

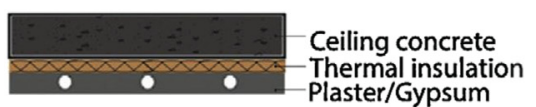

(a) Embedded surface system

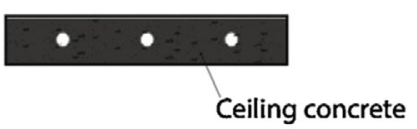

(b) TABS

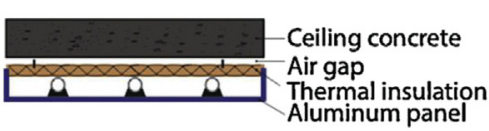

(c) Radiant panel system

Fig. 1. Classification of the radiant heating and cooling system [11]. 
measurements and a subjective survey by Lin et al. showed that radiant heating systems reduce draught risk and local discomfort in the feet region due to small temperature fluctuations and vertical temperature gradients [28]. Even though the RHC system can minimize the draught risk due to excessive air movement, it can cause a sensation of stagnant air, which makes occupants claim more air movement. For this reason, it is necessary to ensure the appropriate air movement or ventilation performance, while reducing the draught risk. The ventilation system (e.g. displacement ventilation) combined with the RHC system has been recommended to provide air movement and ventilation performance in the occupied space with the RHC system.

Although the RHC system can provide improved thermal comfort by utilizing radiant surfaces, the floor surface temperature needs to be carefully considered to prevent the local discomfort because the human body usually is in direct contact with the floor surface. In ASHRAE Standard 55 and ISO EN 7730, the recommended floor surface temperatures are between $17{ }^{\circ} \mathrm{C}$ and $29{ }^{\circ} \mathrm{C}$ $[29,30]$. Particularly for radiant floor cooling, provided the floor surface is not less than $19{ }^{\circ} \mathrm{C}$, the indoor thermal environment conforms well to the comfort standards [9,31]. However, it should be noted that acceptable surface temperatures can differ depending on the type of lifestyle (seated/lying on the floor etc.) and the floor surface materials are important for occupants not wearing shoes $[12,32,33]$.

A simulation study revealed that, in U.S commercial buildings, the radiant cooling system can provide more stable indoor temperature and humidity over a 24-h period than the all-air system [34]. In a field study for an office building with radiant slab cooling, it was demonstrated that the average vertical air temperature difference between the ankle and head was about $0.5 \mathrm{~K}$, and the average draught rate was about $4 \%$, which indicates that radiant slab cooling is effective in reducing local discomfort [25]. It was reported that a chilled ceiling system can achieve identical thermal comfort to that of the all-air system, with a room air temperature
$2 \mathrm{~K}$ higher [27]. Measurements and questionnaires conducted in Dutch schools with TABS installed showed that the users are more satisfied during winter compared to traditional heating systems [35]. Comparative analysis on thermal comfort showed that radiant ceiling cooling achieves more uniform comfort conditions than convective terminals [36]. A recent survey conducted on the users of adjacent buildings with variable air volume (VAV) and radiant cooling system showed that the "satisfied or very satisfied" category increased from $45 \%$ in the zone with the all-air system to $63 \%$ in the zone with the radiant system, as shown in Fig. 3 [37].

Although previous studies have demonstrated that the RHC system can provide thermal comfort for occupants in energyefficient ways, other issues on indoor environment quality need to be considered when designing or operating the RHC system. For example, the room acoustics in a building with TABS can deteriorate due to sound propagation, because the TABS is generally installed without any sound absorber in order to maximize the thermal capacity. To reconcile this conflict between thermal capacity and noise, Machner suggested finding an optimum ceilingcoverage ratio by free-hanging sound absorbers that can minimize the trade-off between thermal and acoustic conditions [38]. Rage et al. showed that the $60 \%$ coverage ratio by floating acoustic panels reduces cooling capacity by $15.8 \%$ and increases the operative temperature by $0.9 \mathrm{~K}$. Both for acoustic and thermal reasons, Rage et al. suggested placing free-hanging acoustic panels or baffles as far from the slab as possible, and combining them with wall absorbers [39].

Regarding the indoor air quality, radiant heating systems are beneficial in reducing dust transportation compared to convective heating systems [5]. Considering that the indoor air is perceived to be better at lower air temperatures [40], people may perceive better indoor air quality in a building with radiant heating systems, because the air temperature can be kept lower than conventional buildings [5]. As the radiant system cannot remove latent load or pollutants, additional ventilation systems need to be incorporated.
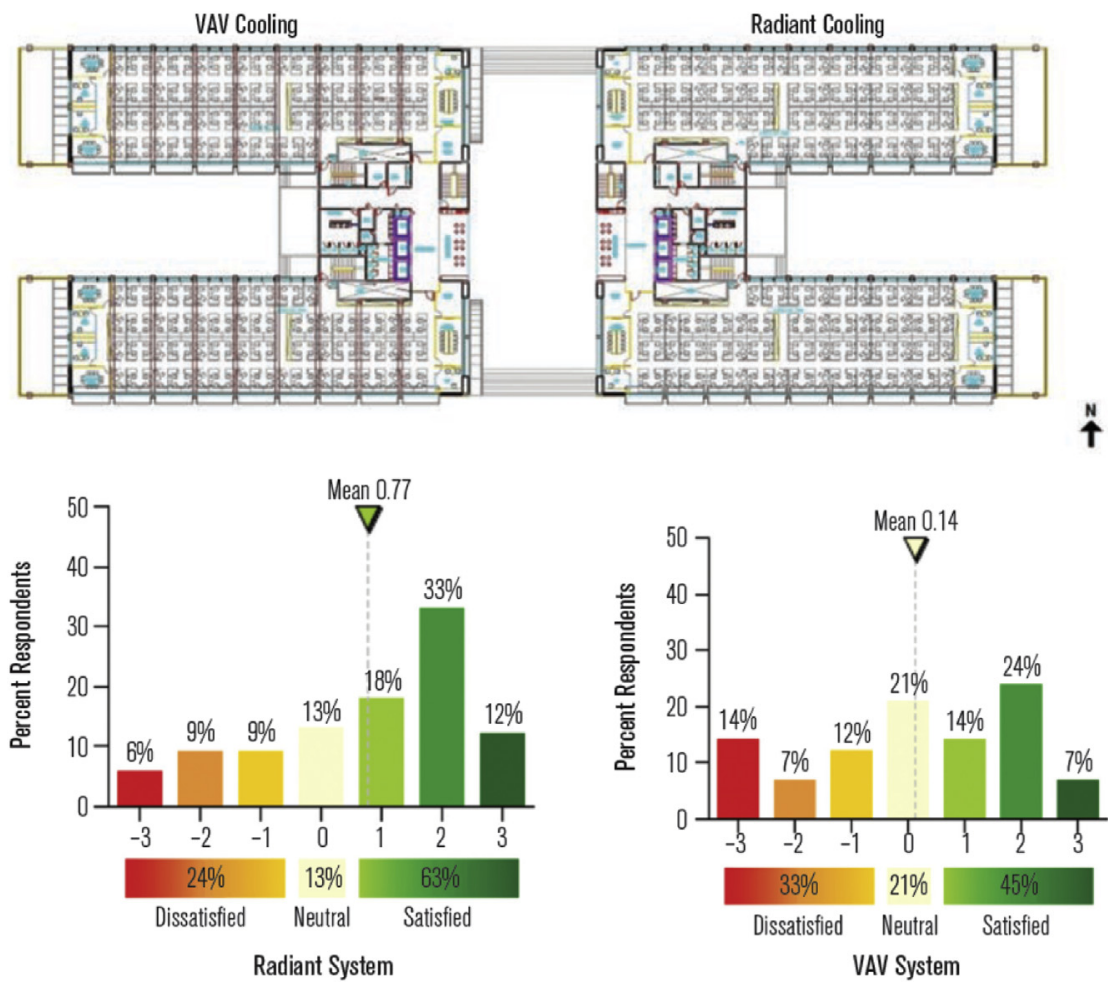

Fig. 3. Occupant survey results: comparison between VAV and Radiant system [37]. 
It was shown that the displacement ventilation system guarantees high levels of indoor air quality for a chilled ceiling system [41] and even for radiant floor heating system [42]. Mixing ventilation can also be combined with the radiant cooling system in order to satisfy not only the ventilation requirement but also thermal comfort [41].

\subsection{Energy performance}

\section{4) What is the core principle of energy saving by the RHC system compared to conventional air systems?}

The thermal medium of the RHC system is usually water, which can transport approximately 3500 times more heat than the same volume of air. Thus, the transportation energy for the thermal medium can be significantly reduced compared to conventional air systems. In addition, the lower water temperature required for heating and the higher water temperature required for cooling can improve the plant efficiency, which contributes to reducing primary energy consumption. In addition, the RHC system can provide an acceptable thermal comfort level by utilizing radiant heat transfer and large surfaces for the heat transfer. This makes it possible to maintain a lower air temperature for heating and a higher air temperature for cooling, resulting in lower energy use for ventilation compared with conventional air systems $[8,9,43,44]$. The large surface area facilitates a small temperature difference for the heat transfer, rendering it possible to use a higher water temperature for cooling and a lower water temperature for heating. In addition to the energy saving effect by lowering the air temperature, further energy saving is obtained with the following principles.

\section{- Thermal medium with high thermal capacity}

The RHC system generally adopts water as the thermal medium, which has a much higher thermal capacity than air. This can result in reducing transporting energy consumption compared to conventional air systems in which the air in the entire room needs to be warmed or cooled. Even though the RHC system requires some energy for the purpose of ventilation, it has been reported that the transporting energy for the radiant cooling system (electricity for fans and pumps) can be reduced to approximately $25 \%$ of the original value (electricity for fans of conventional air systems) [8].

\section{- High thermal mass to reduce peak loads}

In an RHC system with high thermal mass (e.g. TABS), structural floors or slabs can be exploited to store energy. The use of a high thermal mass is effective to flatten energy demand peaks [45-48]. It has been claimed that the cooling capacity of a chiller can be reduced by up to $50 \%$ for a building with TABS installed $[46,49]$. In terms of the water distribution system, if the RHC system is properly designed so that it can take advantage of thermal mass, it is often possible to only operate the pump during the nighttime $[50,51]$, which results in the significant reduction of energy peaks and electricity costs.

\section{- High efficiency for heat sources}

In terms of heat sources, the higher water temperature of radiant cooling systems and the lower water temperature for radiant heating systems enable a chiller, heat pump, boiler etc. to operate at a higher efficiency, which leads to the significant reduction in primary energy consumption. Higher temperature cooling facilitates the use of a higher chilled water supply system or low-lift chiller system, in which the evaporator temperature can be higher than that of the conventional chiller, reducing the compressor work and the energy consumption [52]. Since the RHC system can operate under the condition of the water temperature being close to the room temperature, it is feasible to combine the RHC system with renewable energy sources such as geothermal or solar energy [53-56].

\section{5) What types of computer simulations are available for anal- ysis of the energy performance of the RHC system?}

Extensive studies have been conducted on methods of analyzing the energy performance of the RHC system. The heat transfer mechanism, which is the starting point of the energy analysis, has been investigated by using analytical solutions $[45,46]$, numerical solutions such as finite difference method [31] or finite volume method [57], and building energy simulation tools. In particular, various research on integrating system modules (e.g. radiant slab, hydronic components, boiler, chiller, etc.) into existing simulation programs has been carried out. Therefore, the RHC system is included in all major dynamic building simulation programs for analyzing energy performance and indoor environment [58].

Strand and Pedersen [59] integrated a radiant heating and cooling model into a building energy simulation program, based on the conduction heat transfer method. In the simulation, a heat balance engine calculates heating and cooling loads, and the loads are then passed to the building system simulation module, which calculates the heating and cooling system response [60]. The RHC model is defined as a 'zone equipment', which can be connected with a hydronic loop, thermostat, control valve, primary system, and so on [61].

Laouadi [62] implemented a semi-analytical model of the RHC system in the energy simulation, where the RHC model is composed of two sets: a one-dimensional numerical model to analyze heat transfer within the building and a two-dimensional analytical model to calculate the heat transfer within the radiant medium, as described in Fig. 4 [62]. At each timestep, the twodimensional analytical model determines the net heat flux from the radiant system, which is then passed to a user selected node in the one-dimensional floor structure [63].

Weber and Jóhannesson adopted an RC-network model to simulate TABS as well as a surface radiant system [64]. For analyzing floor heating or cooling, a heat exchanger model is inserted into a piping layer, which divides the floor construction into two parts (above and below the heated/cooled layer), as shown

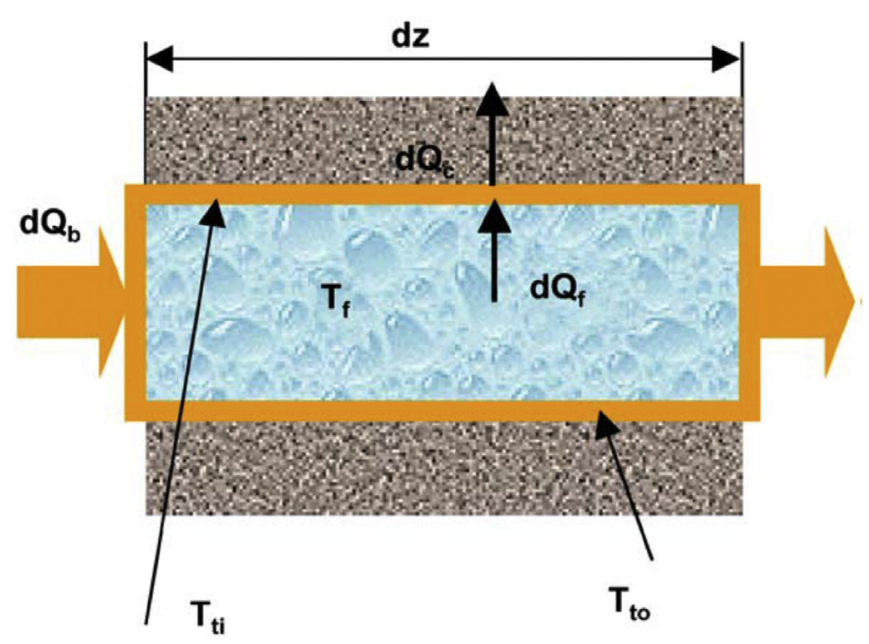

Fig. 4. Heat balance around the tubing, used in the semi-analytical model [62]. 
in Fig. 5. Heat transfer is calculated with a logarithmic temperature difference between the water and the active layer, which is treated as an infinitely conductive plane in the floor slab [65].

Koschenz and Dorer developed a combined RC-conduction transfer model of TABS (Fig. 6) and integrated it in the multi-zone model of a building [45]. The TABS layer is incorporated into the layer definition of the wall, ceiling or floor. The model is applicable to analyze the TABS and can be connected with various mechanical components such as a mixing valve, manifold, boiler, chiller, storage system, controllers, and so on.

As the RHC system is often coupled with ventilation systems for ventilation and latent load handling, the simulation needs to consider the effect of air movement, thermal stratification and thermal uniformity in a space. In addition, the temperature distribution in a radiant surface can affect the thermal capacity or heat transfer coefficient of the RHC system [66]. Computational fluid dynamics (CFD) simulation can be applied to investigate these characteristics and improve the reliability of performance evaluation for the RHC system.

In a numerical study using CFD simulation, Myhren and Holmberg concluded that low temperature heating systems improve indoor climate, reduce the air speed, and reduce temperature difference in the room compared to conventional radiator system. It was also shown that the low temperature heating can lead to
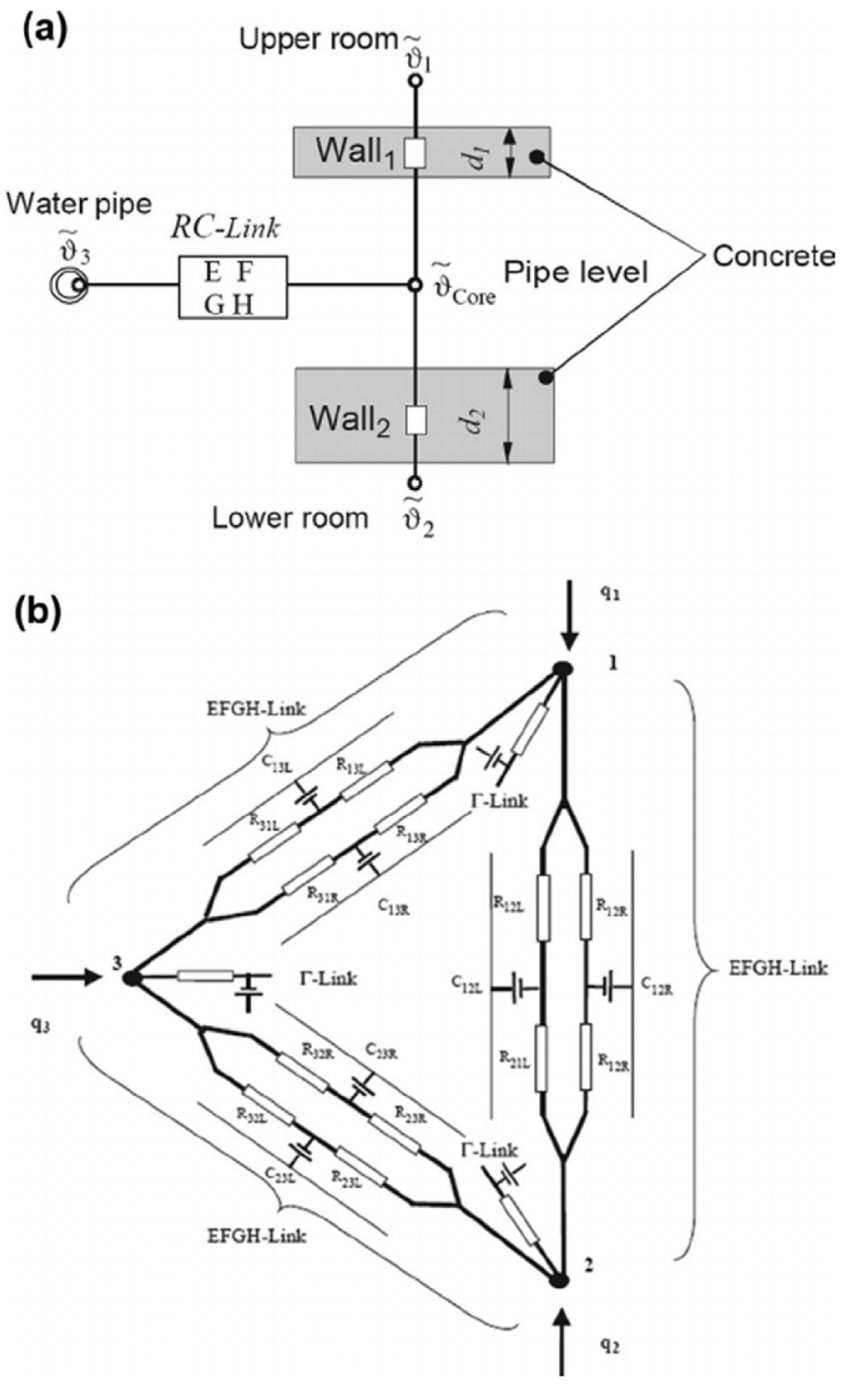

Fig. 5. Modified RC-network model for TABS [64].

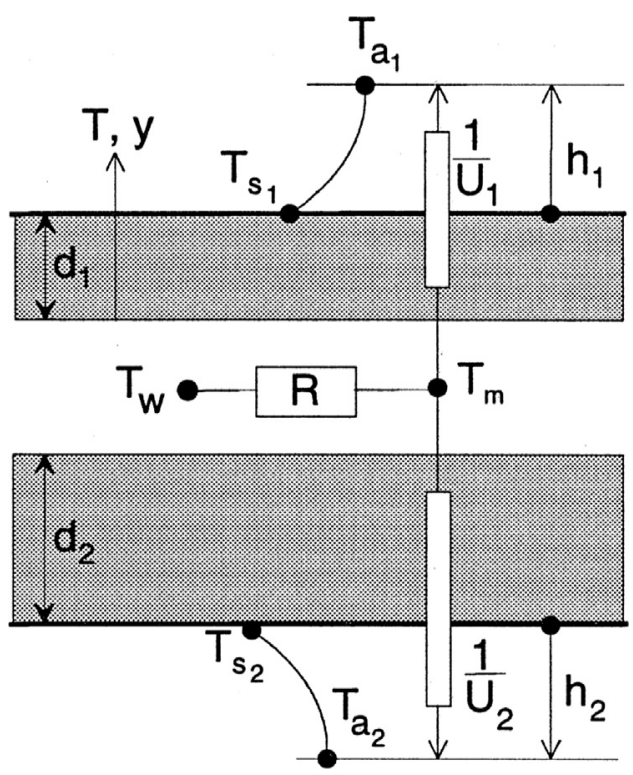

Fig. 6. One-dimensional model to calculate heat transfer through concrete slab [45].

energy saving by lowering the room temperature by up to $1.5 \mathrm{~K}$ while attaining the desired comfort level [67]. Catanlina et al. analyzed thermal comfort in a room with radiant ceiling panel through a combined CFD and experimentation study, where measured data was utilized as the boundary conditions of CFD. The results demonstrated that the cooling ceiling can lower vertical air temperature gradient and can obtain the thermal comfort even for higher metabolism rates or clothing insulation, implying the potential of energy saving [24]. Ning et al. established a CFD model to calculate the surface temperature distribution and cooling capacity for a ceiling panel. CFD analysis results showed that the uniform surface temperature distribution in the ceiling panel can increase the cooling capacity by $43 \%-46 \%$ [68]. Xie et al. conducted CFD simulations to show that temperature non-uniformity in a radiant panel is dependent on inlet water temperature and tube spacing, which also affect the cooling capacity of the ceiling radiant panel [66]. Tye-Gingras and Gosselin developed a CFD model coupled with a semi-analytical radiant panel model, by which the panel surface temperature distribution and local heat transfer coefficients can be fed back to each model at each time step. This coupled approach was used to acquire the optimum solution of panel design for maximizing comfort and minimizing energy consumption of hydronic heating panels [69]. Kim et al. suggested a CFD model coupled with a radiative heat transfer simulation and HVAC control system, by which the required cooling load for achieving the same thermal sensation was evaluated for an all-air system and radiant panel system [70].

For more accurate and extensive analysis of energy performances, some research has been carried out by combining building energy simulation (BES) and computational fluid dynamics (CFD), coupling different simulation tools for analyzing multi-physics in the RHC system (e.g. hydraulic-thermal coupled analysis) and integrating experimental and simulation methods.

\subsection{Design and dimensioning}

6) What are the main parameters that determine heating and/ or cooling capacity of the RHC system?

Essentially, the capacity of the RHC system is determined by the 
heat transfer at each element in the RHC system. This depends on the heat exchange between the radiant surface and the occupied space (convective and radiant heat exchange coefficient), the heat conduction between the surface and the tubes (surface material, type of concrete, type of piping system, slab thickness, and tube spacing), and the heat transport by water (water flow rate and temperature difference between supply and return) [5].

The heat exchange coefficient is a parameter that determines the amount of heat transferred between a surface and the occupied space. Since the total heat transfer is composed of radiant and convective heat transfer, radiant and convective heat transfer coefficients need to be considered to determine the thermal capacity of the RHC system. In general, the radiant heat transfer coefficient can be considered about $5.5 \mathrm{~W} / \mathrm{m}^{2} \mathrm{~K}$, while the convective heat transfer coefficient can vary between 0.3 and $6.5 \mathrm{~W} / \mathrm{m}^{2} \mathrm{~K}$, depending on the position and temperature of the heated or cooled surface. Table 1 summarizes the heat transfer coefficients proposed in previous studies on the RHC system.

At a given average surface temperature and indoor temperature, a surface will deliver the same amount of heat flux to a space regardless of the embedded radiant system type [44]. In practical applications, the heating and cooling capacities of the RHC system are determined based on the following equations from ISO 11855 [10]:

$\mathrm{q}=8.92\left(t_{o}-t_{s, m}\right)^{1.1}$, for floor heating and ceiling cooling

$\mathrm{q}=8\left(\left|t_{o}-t_{s, m}\right|\right)$, for wall heating and wall cooling

$\mathrm{q}=6\left(\left|t_{o}-t_{s, m}\right|\right)$, for ceiling heating

$\mathrm{q}=7\left(\left|t_{o}-t_{s, m}\right|\right)$, for floor cooling

where, $t_{0}$ is the operative temperature of the space and $t_{s, m}$ is the average surface temperature.

The above-mentioned heat transfer coefficients are used to estimate the thermal capacity based on the heat transfer at the radiant surface. This approach is accepted as an efficient way to assess the system feasibility and as a basis for detailed design and operation conditions $[78,79]$. The other approach for the estimation represents the thermal capacity with a lumped thermal resistance and a mean temperature difference between the water and the room, as formulated in Eqs. (5)-(6) [80]. This approach exploits product data from the manufacturer in order to relate the thermal capacity to the system configuration and the water temperature.

$\mathrm{q}=\mathrm{K} \cdot \Delta T^{n}$

$\Delta \mathrm{T}=\frac{T_{S}-T_{r}}{\ln \left[\left(T_{S}-T_{o}\right) /\left(T_{r}-T_{o}\right)\right]}$

where $\mathrm{K}$ is the thermal resistance associated with surface heat transfer coefficients, the resistance of conductive layer, the resistance between pipe and water, etc. $T_{s}, T_{r}$, and $T_{o}$ is supply water temperature, return water temperature, and room operative temperature, respectively. The thermal resistance $\mathrm{K}$ can be determined by the calculation method in ISO 11855, where details about the related parameter are provided for different system types. In addition to the calculation method, testing methods are available to determine the thermal resistance $\mathrm{K}$ for radiant ceiling panels (ASHRAE 138 [21] or EN 14240 [20]) and for embedded systems (EN 1264 [18]) [80].

\section{7) What is the difference, if any, in cooling load calculation between radiant and air systems?}

The calculation of cooling load can be regarded as a starting point for determining the cooling capacity and sizing HVAC equipment for radiant cooling systems. In traditional methods, the cooling load is defined as the rate at which sensible and latent heat must be removed from the space to maintain a constant space air temperature and humidity [81,82]. While the heat gains are composed of convective and radiant components, it is assumed that the convective component is removed immediately, contributing to the cooling load. The radiant component is first absorbed in internal surfaces and eventually transferred by convection to the air, contributing to the cooling load with some time delay. The time delay effect of radiant heat gain is taken into account using heat balance method [82], transfer function [83], radiant time series [84], and so on. However, these methods are based on the assumption that an air system is used for removing the heat gains [11].

Compared to traditional air systems, radiant systems remove heat gains by different heat transfer paths (radiant heat transfer).

Table 1

Heat transfer coefficients of the RHC system.

\begin{tabular}{|c|c|c|c|}
\hline Reference & Total heat transfer coefficient $\left(\mathrm{W} / \mathrm{m}^{2} \mathrm{~K}\right)$ & Radiative heat transfer coefficient $\left(\mathrm{W} / \mathrm{m}^{2} \mathrm{~K}\right)$ & Convective heat transfer coefficient $\left(\mathrm{W} / \mathrm{m}^{2} \mathrm{~K}\right)$ \\
\hline Feustel and Stetiu [8] & $9-12$ & 5.5 & $3.5-6.5$ \\
\hline Rehva [9] & $\begin{array}{l}11.0 \text { (floor heating) } \\
7.0 \text { (floor cooling) }\end{array}$ & - & - \\
\hline CEN [18] & $\begin{array}{l}10.8 \text { (floor heating) } \\
6.5 \text { (floor cooling) }\end{array}$ & - & - \\
\hline Olesen [5] & $\begin{array}{l}\text { 9-11 (floor heating) } \\
7 \text { (floor cooling) }\end{array}$ & 5.5 & \\
\hline Rees and Haves [71] & - & - & 5.9 (ceiling cooling + displacement ventilation) \\
\hline Miriel et al. [72] & - & - & $\begin{array}{l}3.0 \text { (ceiling cooling) } \\
1.2 \text { (ceiling heating) }\end{array}$ \\
\hline Causone et al. [73] & $\begin{array}{l}13.2 \text { (ceiling cooling) } \\
5.8 \text { (ceiling heating) }\end{array}$ & 5.6 & $\begin{array}{l}\text { up to } 4.4 \text { (ceiling cooling) } \\
\text { up to } 0.3 \text { (ceiling heating) }\end{array}$ \\
\hline Okamoto et al. [74] & - & 5.65 & $\begin{array}{l}2.54 \text { (ceiling cooling) } \\
1.69 \text { (ceiling heating) }\end{array}$ \\
\hline Cholewa et al. [75] & - & $\begin{array}{l}5.6 \text { (floor heating) } \\
5.0 \text { (floor cooling) }\end{array}$ & $\begin{array}{l}2.2-3.5 \text { (floor heating) } \\
0.1 \text { (floor cooling) }\end{array}$ \\
\hline Zhang et al. [76] & - & 5.5 & $\begin{array}{l}0.8 \text { (ceiling heating) } \\
2.3 \text { (ceiling cooling) }\end{array}$ \\
\hline Koca et al. [77] & 8.4 (wall heating) & 5.7 & 2.7 (wall heating) \\
\hline
\end{tabular}


Radiant surfaces cool other inside surfaces, resulting in higher heat gain through the building. In addition, radiant heat exchange with non-active surfaces can reduce heat accumulation in the building mass, affecting peak loads [85]. As a result, the revised definition of cooling load for radiant systems needs to be considered.

By defining radiant cooling load as "the heat removed by the radiant ceiling panels", Feng et al. [11] showed that the peak cooling load of a radiant ceiling cooling system can be $7 \%-35 \%$ higher than that of an air system. It has been claimed that the reason of cooling load difference is due to the reduction of heat accumulation in the building mass due to the direct removal of radiant heat gains, and heat absorption by non-active surfaces due to relatively higher air temperature $[11,85]$. Nui et al. conducted a study on cooled ceiling dynamics showing that the direct heat absorption due to cooled ceiling reduces the heat capacity of the building envelope, resulting in increased cooling load [86]. Considering this difference in cooling load, Feng et al. proposed a revised calculation scheme for the cooling load of radiant systems, as illustrated in Fig. 7.

In addition, the direct absorption of radiant heat gain significantly affects the cooling load of buildings with high solar radiation. The radiant floor in Suvarnabhumi International Airport in Bangkok, Thailand was designed to remove $70-80 \mathrm{~W} / \mathrm{m}^{2}$ of heat and the radiant floor could absorb up to $50 \mathrm{~W} / \mathrm{m}^{2}$ by radiation [87]. The potential for radiant cooling systems to achieve higher cooling capacity with solar radiation has been the subject of numerous studies, and certain coefficients representing the improvement of steady-state heat transfer have been proposed [88-90]. Causone et al. [89] defined and calculated the direct solar load (DSL) in order to quantify the solar heat gain directly converted to cooling load due to the action of the radiant ceiling cooling system. A cooling load calculation scheme was also suggested using the ratio (so called F-ratio) of solar heat gain directly converted to cooling load. As the F-ratio was estimated with the steady-state calculation using a lighting simulation, Feng et al. proposed a new equation to calculate the dynamic effect of direct solar radiation on the capacity of the radiant floor cooling. By using dynamic simulation, it was shown that the solar radiation absorption can increase the cooling capacity up to $130-140 \mathrm{~W} / \mathrm{m}^{2}$ [80]. Similarly, Arcuri et al. [91] suggested the direct water load (DWL) to evaluate the real cooling capacity of a radiant ceiling panel, because the DWL is immediately removed by the radiant surface and it does not contribute to the cooling load of the indoor environment.

\subsection{Control}

8) What type of control parameters are commonly used for the RHC system? Which control methods are effective for thermal comfort and energy saving?

In practical applications, supply water temperature and water flow rate are commonly used for the RHC system controls. An outdoor temperature reset control is typically applied, which modulates the supply water temperature depending on the outdoor air temperature and controls water flow rate to each room according to the room set point temperature [23,92]. It is also recommended that the average water temperature (mean value of supply and return water temperature) be controlled according to the outside and/or indoor temperature because this can result in faster and more accurate control of the thermal output to the space [23].

In certain cases, the slab or floor surface temperatures could be used as a controlled parameter in order to improve energy efficiency or to avoid local discomfort $[93,94]$. It has been suggested that the floor surface temperature needs to be selected as a control parameter of radiant floor cooling systems, in order to avoid overcooling of the floor due to the sudden increase of cooling loads [31]. In a building with a radiant floor heating system, the improper installation of a sensor that measures the floor surface temperature can lead to under-heating or local over-heating conditions, especially when the floor covering and solar radiation significantly affect the temperature distribution in the floor surface [53]. When the TABS is used as a primary heating system for comfort heating, the heating system should be wired in series with a slab-sensing thermostat, which acts as a limit switch to control the maximum surface temperatures $\left(27^{\circ} \mathrm{C}-29^{\circ} \mathrm{C}\right)$ [6].

For the system configuration, Fig. 8 shows the principal diagram for the RHC system control [16]. By using the shut off valve (SOV), a type of three-way diverting valve, hot or chilled water can be selectively circulated in a hydronic loop. The mixing valve (MX) is used to control the supply water temperature depending on the outdoor air temperature. Control valves installed in the manifold are used to control the water flow rate to each thermal zone. Although this configuration can provide both heating and cooling, it should be noted that the design water flow rate to each zone can differ from season to season because heating and cooling loads in a multi-zone building will vary with the season. In this case, the

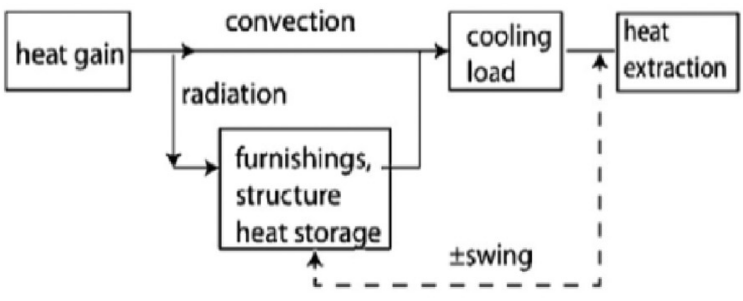

ASHRAE Fundamental (2009)

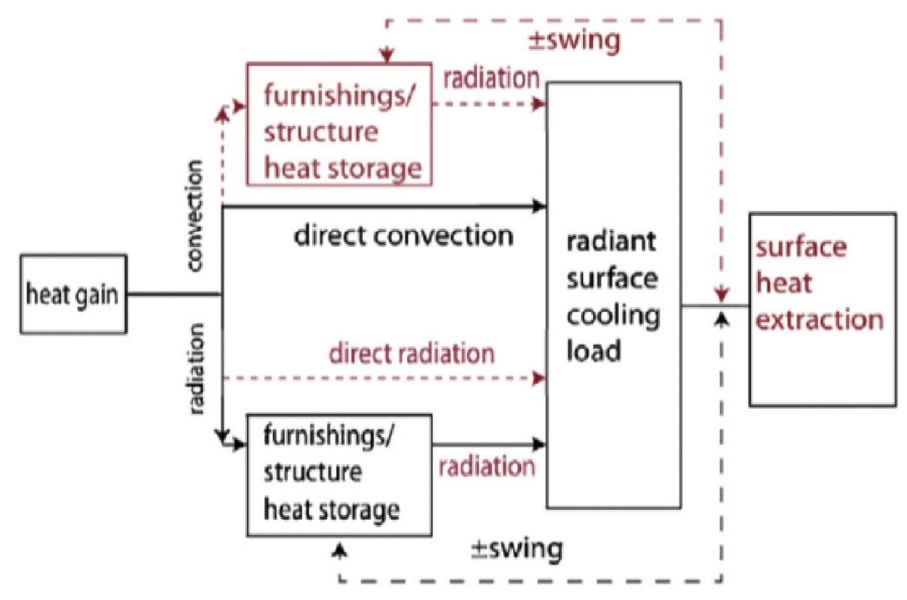

Proposed diagram when radiant system involved

Fig. 7. Cooling load calculation schemes for air and radiant system [11]. 


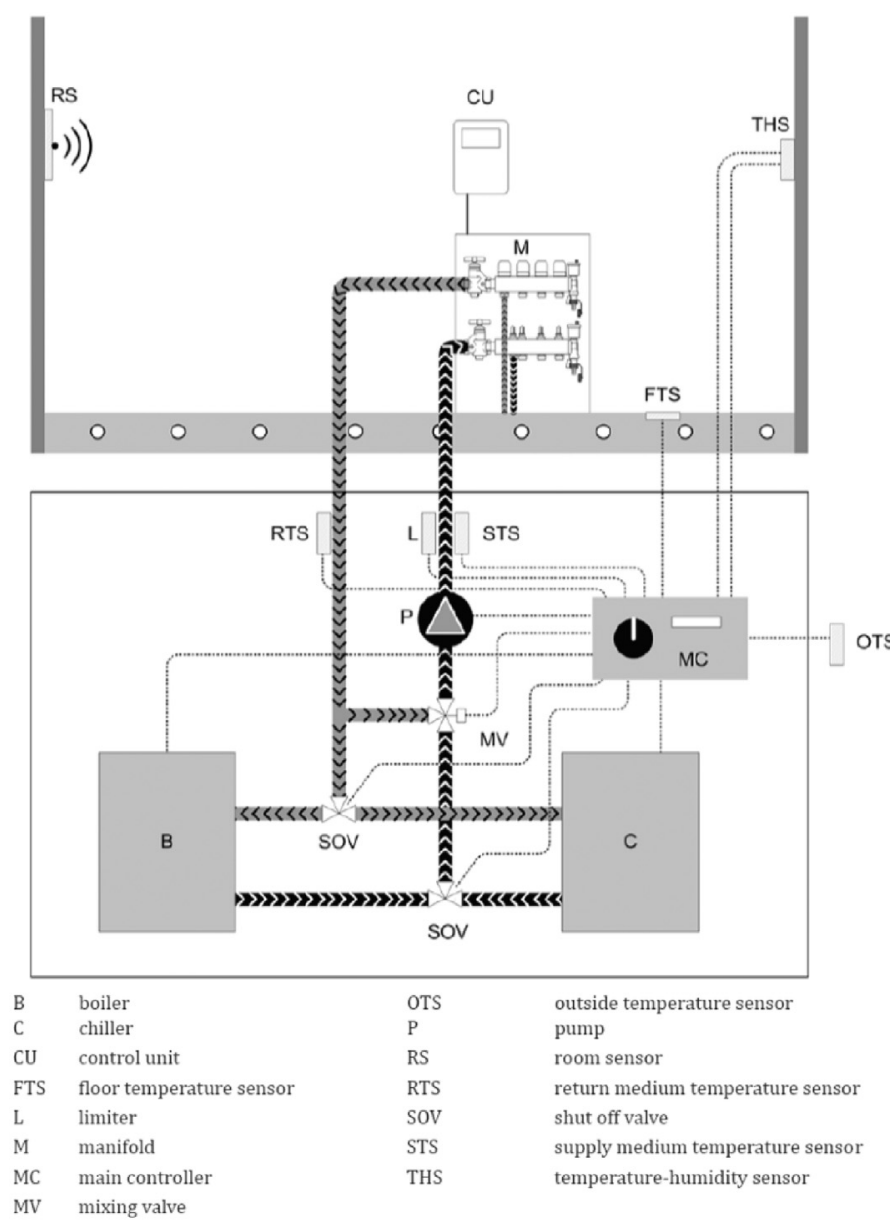

Fig. 8. Principal diagram of the control system for an embedded radiant heating and cooling system [16].

application of dynamic balancing could be feasible in order to supply different design water flow rates for the heating and cooling seasons [95].

In particular, much attention should be paid to control the radiant cooling system to prevent surface condensation. To do this, the supply water temperature should be controlled so that the surface temperature does not become less than the highest dewpoint temperature in the conditioned zones [31]. This can be effectively achieved by limiting the supply water temperature to be higher than the dew-point temperature.

For the improved comfort and further energy savings, individual room temperature controls need to be implemented in buildings with several thermal zones [96]. For the indoor temperature, it is preferable to control room temperature as a function of the operative temperature in order to achieve better thermal comfort [97].

9) What control strategies can be applied to overcome the difficulty in the control (e.g. under-cooling or over-heating problems) of the high thermal mass RHC system?

Radiant systems with large surface areas and small temperature differences between surfaces and the occupied space have a significant level of self-regulation. Small changes in room temperature will significantly change the heat exchange. The systems are thus not responding slowly to compensate for changes in internal loads, etc. However, if room temperature level needs to be changed during the day, the thermal inertia of the systems is important.
Due to the thermal mass of the radiant structure, the continuous operation with a water temperature that is too low or too high can result in under-cooling or over-heating problems [51]. In addition, the high thermal inertia of TABS can often cause difficulty in the control; different comfort requirements of the different rooms included in the same hydraulic zone, the need for manual switching between the heating and cooling mode, unnecessarily high energy consumption for water circulation, and so on [47].

It has been reported that these problems can be solved by limiting the operation time (e.g. operating the system only during the nighttime) or using intermittent operation of the circulation pump. Gwerder et al. suggested an intermittent operation with pulse width modulation (PWM) control, considering the prediction uncertainty of heat gains during operation [47], which proved to reduce the pumping energy by $50 \%$ more than the continuous pump operation [98]. Olesen et al. also demonstrated that the operation time of the TABS can be limited by operating the system only during nighttime or using an intermittent operation for the circulation pump [50].

In order to comply with the different comfort requirements, TABS needs to be designed with proper zoning and needs to be operated with a zone control by which the supply water temperature or the flow rate can be controlled from zone to zone [51]. As each zone can require its own heating and cooling curve, rooms with similar heat gains need to be grouped together [99]. It is essential to separate the building into sufficient zones with TABS, because under-cooling can occur when a low temperature is used for rooms with low heat gains or for unoccupied rooms [49]. The topology of the distribution system should also be carefully designed to cope with the different heating and cooling curves of each zone [99]. In order to handle the different heat gains and comfort criteria in the different rooms aggregated into the same hydronic circuit, Gwerder et al. developed the unknown but bounded (UBB) concept, by which heating and cooling curves are defined based on the upper and lower bounds of heat gains [47]. It was shown that this control strategy enables the automated control of TABS, while allowing automatic switching between cooling and heating modes for variable comfort criteria.

In the most recent review on the control of TABS, Romani et al. [100] classified the control strategies into on/off criteria (including night operation and intermittent operation), supply temperature control, pulse width modulation, model predictive control, adaptive control, and gain scheduling control. Among the control strategies, the supply temperature control with heating and cooling curves was reported as common for most TABS controls [100]. A dynamic simulation study [50] showed that the control of water temperature (supply or average) as a function of outside temperature could provide the best comfort and energy performance.

Some advanced strategies such as model predictive control (MPC) have been proven to be effective to overcome under-cooling or over-heating problems. The predictive control adjusts the heat supply in advance and counteracts the long response time of the embedded heating system [101], which is effective in mitigating the under-cooling or over-heating. Zakula et al. implemented an MPC to determine the cooling strategy based on weather and load prediction during the next $24 \mathrm{~h}$ [102]. Feng et al. suggested a first order MPC model to define the valve opening that minimizes energy consumption and uncomfortable time duration [103]. A predictive control using artificial neural network (ANN) was proven to mitigate over-heating in buildings with a radiant floor heating system [104], as shown in Fig. 9. It has been claimed that a generalized predictive control (GPC) can compensate for not only a large thermal lag but also the set-point temperature change [105]. The MPC was implemented into a real controller, proving that it can proactively guide the system transit from an unoccupied to an 
occupied condition while maintaining acceptable thermal comfort.

Comprehensive models used to represent the MPC have been developed using Simulink [101], EnergyPlus [106], and TRNSYS [107]. To implement the MPC in a real building, most MPC formulations exploit the linearized state-space models, discretized versions of physics-based models or a simple linear model, because the controller is usually developed on a simpler physics-based and data-driven model [108]. Further control strategies for predictive control can be found in other previous works [109-112].

10) What strategies should be applied to prevent the condensation problem with the radiant cooling system, especially in hot and humid climates?

Table 2 lists previous studies that demonstrated the feasible application of the radiant cooling system in hot and humid climates. Saber et al. [113] demonstrated the applicability of radiant cooling panels coupled with a dedicated outdoor air system (DOAS) (Fig. 10) in the hot and humid climate of Singapore. Chiang et al. claimed that a supplementary ventilation system is indispensable when implementing a radiant cooling system in the subtropical climate of Taiwan, because the ventilation system can enhance the cooling capacity of the cooling ceiling [114]. Memon et al. showed that cooling towers can be used to regenerate cooling water for the radiant cooling system in the hot and humid climate of Pakistan [115]. Simmonds et al. demonstrated that the radiant floor cooling system can be successfully applied to the large public space of Bangkok airport, where a variable-volume displacement ventilation system was installed, combined with a radiant floor cooling system, in order to cope with a large latent load [87], as illustrated in Fig. 11 [116]. Song et al. [117] showed that a radiant floor cooling system integrated with a dehumidified ventilation system can solve the condensation problem in the hot and humid season of Korea. Kim and Leibundgut [118] demonstrated that radiant panels connected with a convective terminal can not only prevent surface condensation but also increase the overall cooling capacity in a tropical climate. Several researchers have shown that radiant cooling systems are successful in hot and humid climates when combined with the desiccant cooling for removing latent load [119-123], as illustrated in Fig. 12.
To prevent condensation on cooled surfaces, the supply water temperature must be controlled at a higher than dew-point temperature of the conditioned space. Although the dew-point temperature distribution can be non-uniform in the conditioned room, it is somewhat difficult to deploy dew-point sensors with high spatial resolution due to the limitation of cost, maintenance, and so on. For practical reasons, Jin et al. [135] suggested that the dewpoint temperature above the wet source should be monitored and control measures should be taken to prevent the condensation. Lim et al. [31] suggested that the supply water temperature for floor cooling should be determined according to the dew-point temperature of the most humid room, while the water flow rate should be controlled for individual rooms. If the space is cooled by multiple panels, a dew-point sensor can be placed at the inlet to the first radiant panel for each group controlled by a control valve [136]. In practical applications, several dew-point sensors can be placed in different rooms or zones, and the maximum dew-point temperature is used to control the supply water temperature [137]. The optimum location and/or numbers of the dew-point sensor is dependent on the climate, building use, internal gains and so on; therefore, further studies are needed to determine the location and/ or number of the dew-point sensors with sufficiently high resolution, in order to minimize the condensation risks in non-uniform thermal environments.

A sudden increase of internal load or humid infiltration can deteriorate the stability of the condensation control. In particular, an increased occupancy in conference rooms or local high infiltration rates, which are often caused by opened windows or building entrances [78], can become a disturbance to control the humidity. Under this condition, the radiant cooling system should respond quickly to the disturbance; however, its rate of response is limited due to the high thermal inertia. For this reason, the condensation control strategies should be implemented with the safety margin of $1-2 \mathrm{~K}$. Song et al. showed that the difference between the floor surface and dew-point temperature should be controlled to be always greater than or equal to $2 \mathrm{~K}$ considering the safety rate [117]. With regard to the chilled ceiling system, Hao et al. claimed that the surface temperature of the chilled ceiling should be at least $1 \mathrm{~K}$ higher than the dew-point temperature of the indoor air in order to prevent the condensation on the chilled ceiling [27].

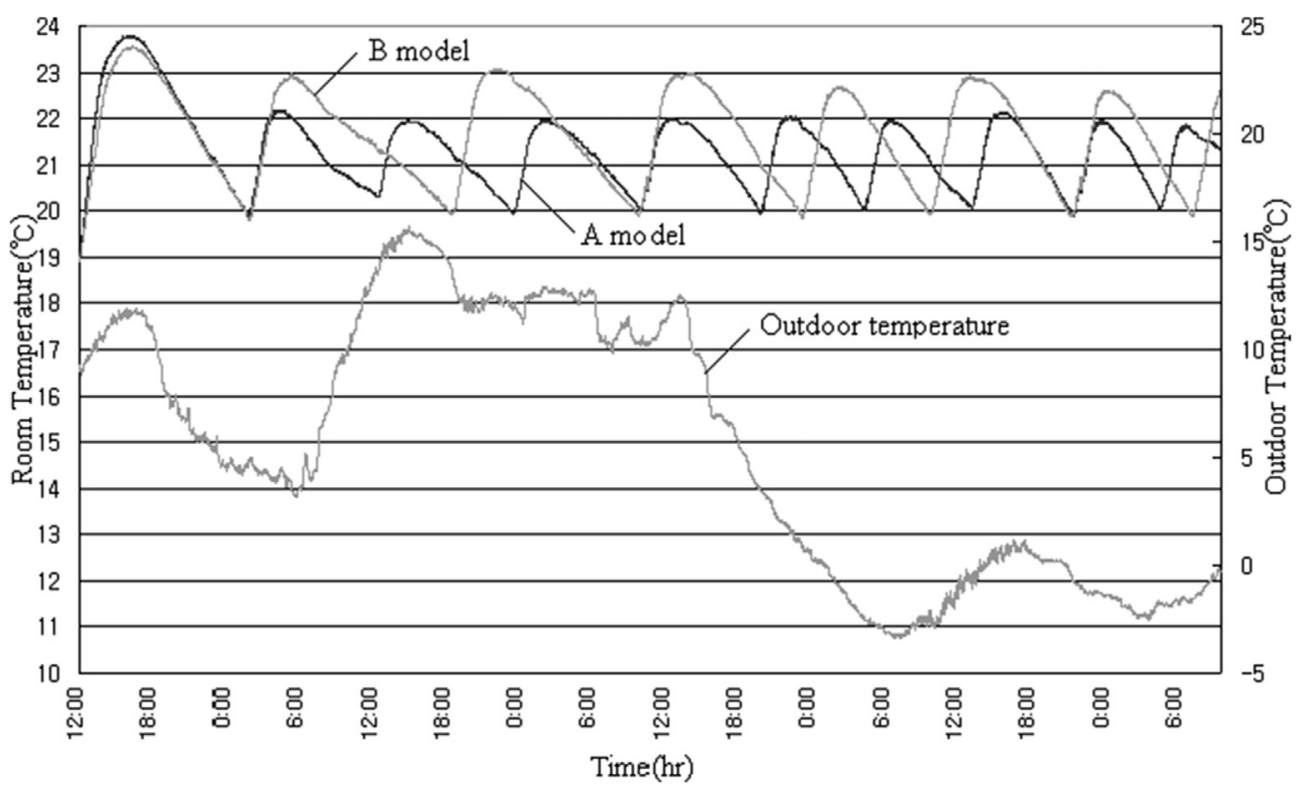

Fig. 9. Mitigation of the overheating by predictive control (Model A: predictive control, Model B: 2-position on/off control) [104]. 
Table 2

Studies on radiant cooling systems in hot and humid climates.

\begin{tabular}{|c|c|c|c|c|c|}
\hline Literature & Location (Climate) & Application & Dehumidification system & $\begin{array}{l}\text { Chilled water } \\
\text { temperature }\end{array}$ & Key strategy and result \\
\hline Hao et al. [27] & Beijing, China & Office & $\begin{array}{l}\text { Displacement ventilation and } \\
\text { desiccant dehumidification for } \\
\text { chilled ceiling }\end{array}$ & $15^{\circ} \mathrm{C}$ & $\begin{array}{l}\text { Desiccant dehumidification is } \\
\text { dedicated to control indoor } \\
\text { humidity and prevent surface } \\
\text { condensation. }\end{array}$ \\
\hline Lim et al. [31] & Seoul, Korea & Residential & $\begin{array}{l}\text { Radiant floor cooling only (outdoor } \\
\text { reset control of supply water } \\
\text { temperature) }\end{array}$ & $16-21^{\circ} \mathrm{C}$ & $\begin{array}{l}\text { Supply water temperature should } \\
\text { be controlled according to the dew- } \\
\text { point of the most humid room }\end{array}$ \\
\hline Simmonds et al. [87] & Bangkok, Thailand & Airport & $\begin{array}{l}\text { Displacement ventilation for } \\
\text { radiant floor cooling }\end{array}$ & $13^{\circ} \mathrm{C}$ & $\begin{array}{l}\text { Variable-volume displacement } \\
\text { ventilation (supply air at } 24^{\circ} \mathrm{C} \text { ) } \\
\text { prevents condensation on the floor } \\
\text { (surface temperature at } 21^{\circ} \mathrm{C} \text { ) }\end{array}$ \\
\hline $\begin{array}{l}\text { Kim and Leibundgut [118], } \\
\text { Kim and Leibundgut [124] }\end{array}$ & Singapore & Office & $\begin{array}{l}\text { An airbox convector in series to a } \\
\text { chilled ceiling }\end{array}$ & $18-21^{\circ} \mathrm{C}$ & $\begin{array}{l}\text { An air convector connected to } \\
\text { chilled ceiling contribute to } \\
\text { reduced condensation risks }\end{array}$ \\
\hline $\begin{array}{l}\text { Zhang and Niu [122] } \\
\text { Niu et al. [125] }\end{array}$ & Hong Kong & Office & $\begin{array}{l}\text { AHU or desiccant cooling for chilled } \\
\text { ceiling }\end{array}$ & Not specified & $\begin{array}{l}\text { Air dehumidification and } \\
\text { ventilation system should be } \\
\text { operated at least } 1 \text { h earlier than the } \\
\text { operation of ceiling panels. }\end{array}$ \\
\hline Memon et al. [115] & Sindh, Pakistan & School & $\begin{array}{l}\text { Ventilation air pre-cooled by the } \\
\text { cooling tower water }\end{array}$ & $\begin{array}{l}<27{ }^{\circ} \mathrm{C} \text { (cooling } \\
\text { tower water) }\end{array}$ & $\begin{array}{l}\text { Radiant cooling utilizing cooling } \\
\text { tower water can be applicable for } \\
\text { naturally ventilated spaces. }\end{array}$ \\
\hline Saber et al. [113] & Singapore & Office (Lab) & $\begin{array}{l}\text { Decentralized DOAS (DDOAS) for } \\
\text { chilled ceiling }\end{array}$ & $17-19^{\circ} \mathrm{C}$ & $\begin{array}{l}\text { Supply air of DDOAS needs to be } \\
\text { determined considering latent load, } \\
\text { CO2 level, preferred air movement } \\
\text { level. }\end{array}$ \\
\hline Song et al. [117] & Seoul, Korea & Residential & $\begin{array}{l}\text { Dehumidified ventilation system } \\
\text { for radiant floor cooling }\end{array}$ & $16-24{ }^{\circ} \mathrm{C}$ & $\begin{array}{l}\text { Outdoor reset control and indoor } \\
\text { temperature feedback control is } \\
\text { effective to lower dew-point } \\
\text { temperature and to respond to } \\
\text { internal load changes. }\end{array}$ \\
\hline Seo et al. [126] & Seoul, Korea & Residential & $\begin{array}{l}\text { Controlled outdoor cooling system } \\
\text { for radiant floor cooling }\end{array}$ & Not specified & $\begin{array}{l}\text { Condensation is prevented by } \\
\text { operating 'outdoor air cooling' unit } \\
\text { when temperature difference } \\
\text { between floor surface and dew- } \\
\text { point is less than } 2{ }^{\circ} \mathrm{C}\end{array}$ \\
\hline Binghooth and Zainal [127] & Malaysia & $\begin{array}{l}\text { Environment } \\
\text { chamber }\end{array}$ & Desiccant wheel for chilled ceiling & $6-10^{\circ} \mathrm{C}$ & $\begin{array}{l}\text { Due to humidity reduction by } \\
\text { desiccant wheel, condensation does } \\
\text { not occur when the panel surface } \\
\text { temperature is } 14^{\circ} \mathrm{C} \text { with } \mathrm{RH} \text { is } 50 \% \text {. }\end{array}$ \\
\hline Kang Zhao et al. [128] & Xi'an, China & Airport & $\begin{array}{l}\text { Displacement ventilation for } \\
\text { radiant floor cooling }\end{array}$ & $14-18^{\circ} \mathrm{C}$ & $\begin{array}{l}\text { Dry fresh air }\left(20^{\circ} \mathrm{C}, 8-10 \mathrm{~g} /(\mathrm{kg} \mathrm{DA})\right) \\
\text { forms a "dry air layer" that protects } \\
\text { the } \\
\text { radiant floor surface from } \\
\text { condensation. }\end{array}$ \\
\hline Hu and Niu [129] & $\begin{array}{l}\text { Beijing, } \\
\text { Qingdao, } \\
\text { Shenzhen, } \\
\text { Tianjin, } \\
\text { In China }\end{array}$ & $\begin{array}{l}\text { Residential, } \\
\text { Airport, } \\
\text { Office (atrium) } \\
\text { Railway station }\end{array}$ & $\begin{array}{l}\text { Low-temperature dehumidifier, } \\
\text { solid and liquid desiccant systems } \\
\text { for radiant floor cooling and chilled } \\
\text { ceiling }\end{array}$ & $16-20^{\circ} \mathrm{C}$ & $\begin{array}{l}\text { Solid or liquid desiccant systems } \\
\text { can lower moisture content to } 1 \\
-4 \mathrm{~g} / \mathrm{kg} \text {. }\end{array}$ \\
\hline Zhao et al. [130] & Shenzhen, China & Office & $\begin{array}{l}\text { Liquid desiccant AHU for radiant } \\
\text { ceiling panel }\end{array}$ & $17.5^{\circ} \mathrm{C}$ & $\begin{array}{l}\text { Liquid desiccant system was used to } \\
\text { control indoor humidity, while } \\
\text { radiant panels and dry FCU were } \\
\text { used to control indoor temperature. }\end{array}$ \\
\hline Khan et al. [131] & Hyderabad, India & Office & $\begin{array}{l}\text { DOAS for radiant floor and ceiling } \\
\text { cooling }\end{array}$ & $16^{\circ} \mathrm{C}$ & $\begin{array}{l}\text { Condensation occurs on the cooling } \\
\text { coil of the DOAS, resulting in } \\
\text { reduced dew-point temperature of } \\
\text { supply air }\end{array}$ \\
\hline $\begin{array}{l}\text { Nutprasert and } \\
\quad \text { Chaiwiwatworakul [132] }\end{array}$ & Bangkok, Thailand & Laboratory & $\begin{array}{l}\text { Dehumidification ventilation } \\
\text { system for wall and ceiling panels }\end{array}$ & 21 or $25^{\circ} \mathrm{C}$ & $\begin{array}{l}\text { To raise chilled water temperature } \\
\text { by } 2 \mathrm{~K} \text { in case of highly-humid } \\
\text { outdoor air can reduce } \\
\text { condensation occurrence to } 1 \% \text { of } \\
\text { total operation hours }\end{array}$ \\
\hline Ameen and Mahmud [133] & $\begin{array}{l}\text { Pulau Pinag, } \\
\text { Malaysia }\end{array}$ & $\begin{array}{l}\text { Environmental } \\
\text { chamber }\end{array}$ & $\begin{array}{l}\text { Desiccant dehumidification for } \\
\text { chilled ceiling }\end{array}$ & $13^{\circ} \mathrm{C}$ & $\begin{array}{l}\text { With an independent desiccant } \\
\text { dehumidification system, } \\
\text { condensation does not occur at } \\
\text { even at } 15^{\circ} \mathrm{C} \text { chilled panel } \\
\text { temperature }\end{array}$ \\
\hline Yau and Hasbi [134] & Malaysia & Office & AHU for chilled slab & $22{ }^{\circ} \mathrm{C}$ & $\begin{array}{l}\text { A downsized AHU prevents } \\
\text { condensation on the chilled slab, } \\
\text { while providing adequate } \\
\text { ventilation rate. }\end{array}$ \\
\hline
\end{tabular}




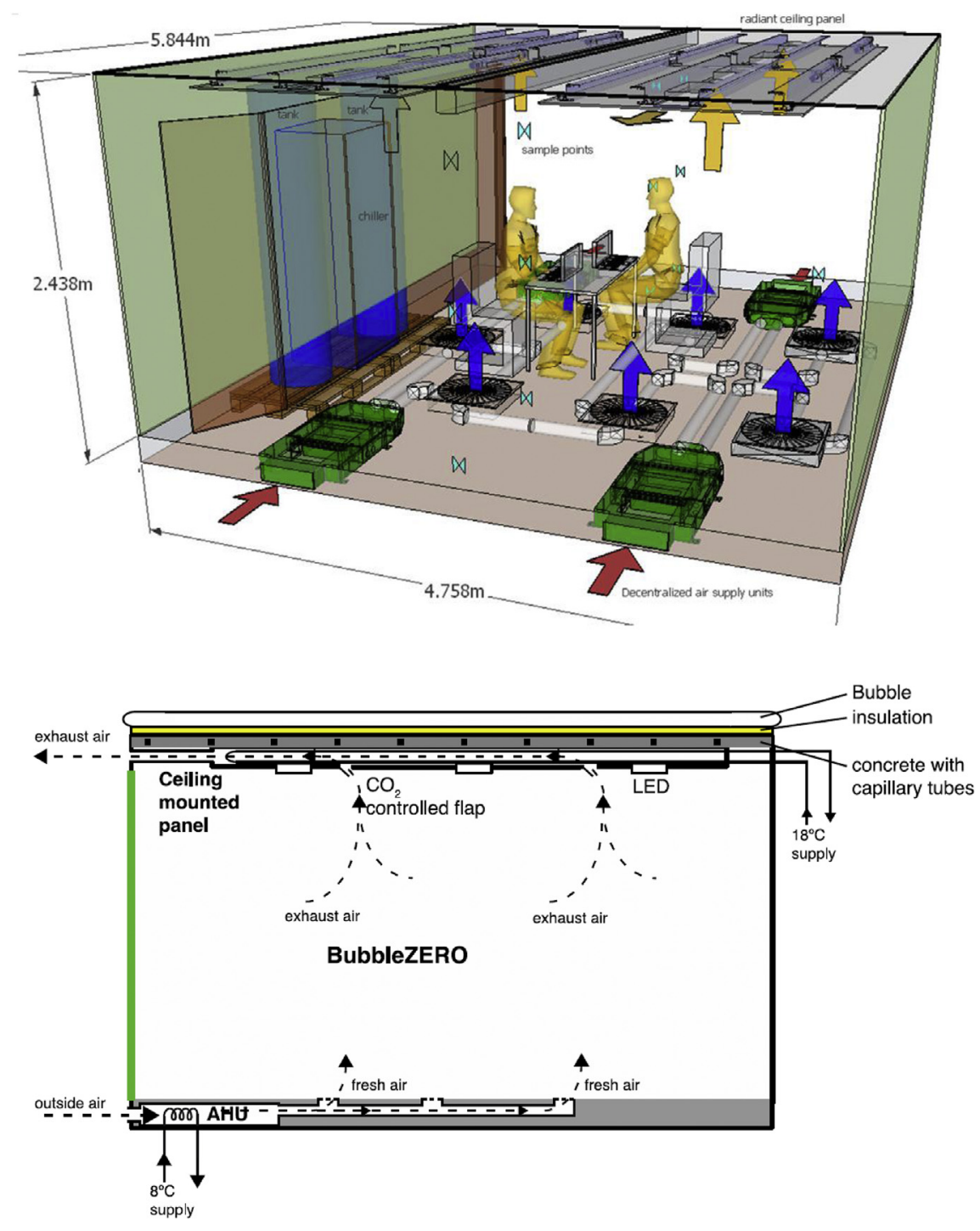

Fig. 10. Radiant cooling system coupled with DOAS system [113,123].

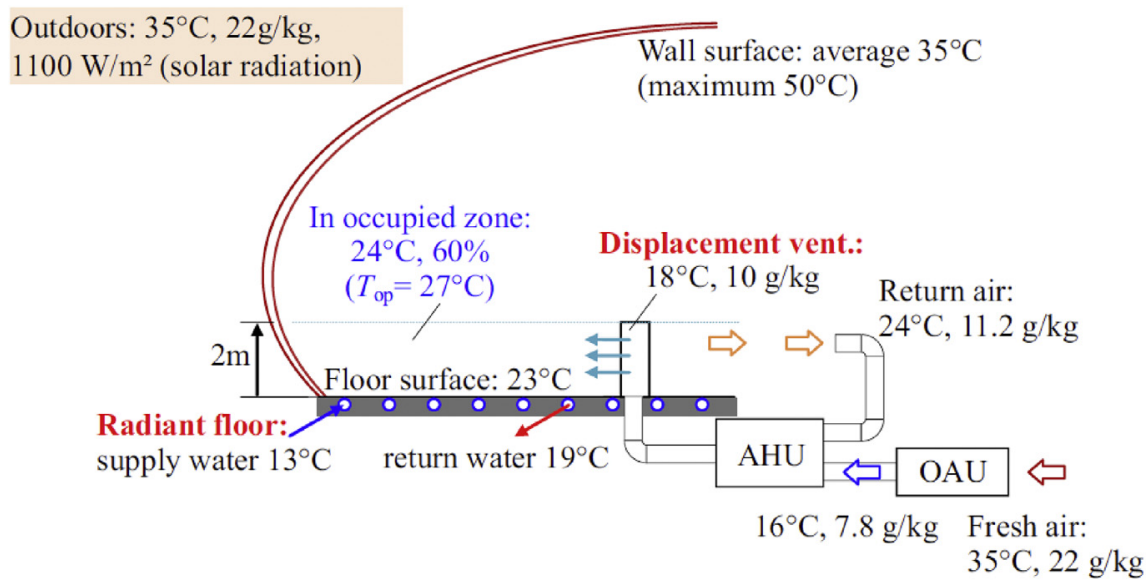

Fig. 11. Schematic of the radiant floor cooling system in Bangkok Airport $[87,116]$.

Novoselac and Srebic proposed that the ceiling surface temperature should be $1 \mathrm{~K}$ above the dew-point temperature of the exhaust air [138]. For TABS, Olesen et al. claimed that the supply water temperature should be controlled to be equal to the dew-point temperature of the occupied space in order to provide the maximum amount of cooling without condensation risks [50]. 


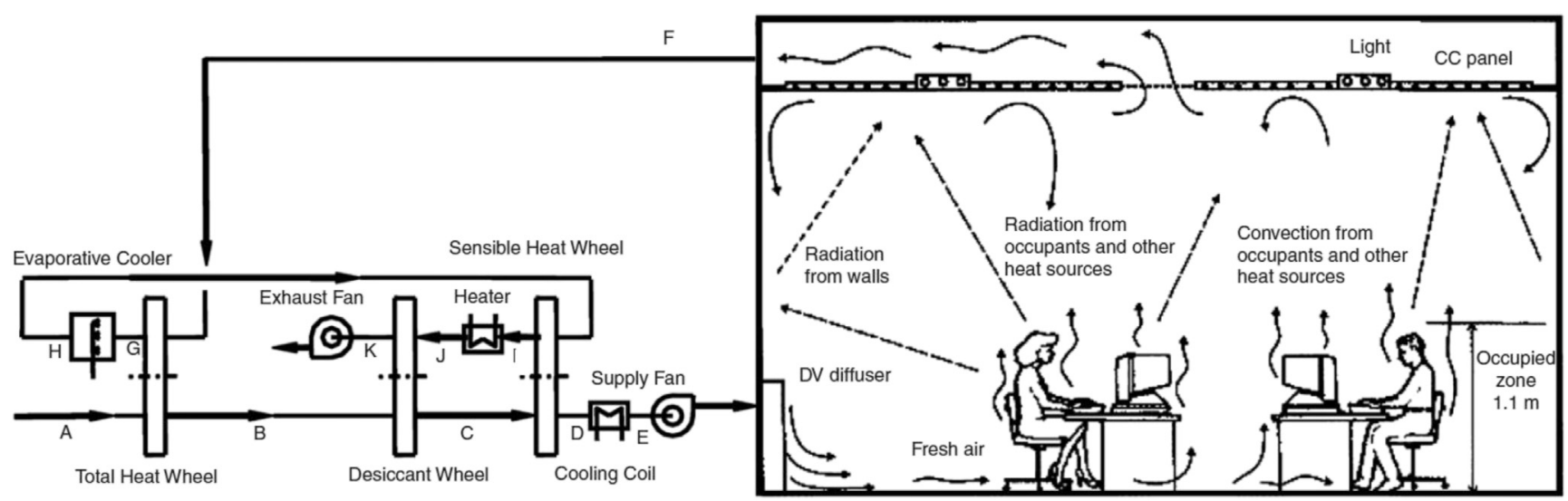

Fig. 12. Chilled ceiling system with desiccant cooling for a hot and humid climate [27].

Since this limitation of the water temperature would lower the cooling capacity, a dehumidification system needs to be integrated with the radiant cooling system in humid climates [31,126,139], as shown in Fig. 13. This integration can reduce the indoor humidity level and allow a higher cooling capacity of the radiant system [23]. Considering that condensation often occurs during the start-up period, it is also recommended to apply an earlier start of the ventilation system and gradual start of the radiant cooling system $[2,37,140,141]$. The air dehumidification and ventilation system should be operated at least $1 \mathrm{~h}$ earlier than the operation of the ceiling panels. Otherwise, condensation can occur. However, if a building is well sealed and the air infiltration rate is less than $0.05 \mathrm{~h}^{-1}$ at night, condensation does not occur even without an earlier operation of the dehumidification [122]. Besides the control strategies such as limiting the water temperature or reducing the dew-point temperature, an alternative can be implemented by using window contacts that cut off the water supply when windows are open [8].

\section{Summary and conclusions}

Since the radiant heating and cooling system was introduced as a solution for environment control system, it has proven to be comfortable and energy-efficient technology for the built environment. Many studies, including field research and surveys, have demonstrated that the RHC system could improve thermal comfort levels by providing a uniform thermal environment and minimizing local discomfort compared with conventional air systems. Energy analysis using dynamic building simulation has shown that the RHC system can enhance energy saving potential by utilizing radiant heat transfer, high thermal capacity of water, the high thermal mass and integration with renewable energy sources.

For the design and dimensioning of the RHC system, many studies have determined the proper heat transfer coefficients for radiant surfaces, which are essential for estimating thermal output by the RHC system. Several important heat transfer coefficients have been defined in the international standard ISO 11855, which deals with the comfort criteria, determination of heating and cooling capacity, design and dimensioning, installation, and control of the RHC system.

For improving thermal comfort and energy performances, control strategies need to be used for the RHC system, such as average water temperature control depending on outdoor temperature, predictive control models, hydronic balancing strategies, and so on. The incorporation of a ventilation system with the RHC system makes it possible to cope with latent load and to prevent condensation risks, demonstrating that the radiant cooling system can be successfully implemented even in hot and humid climates.

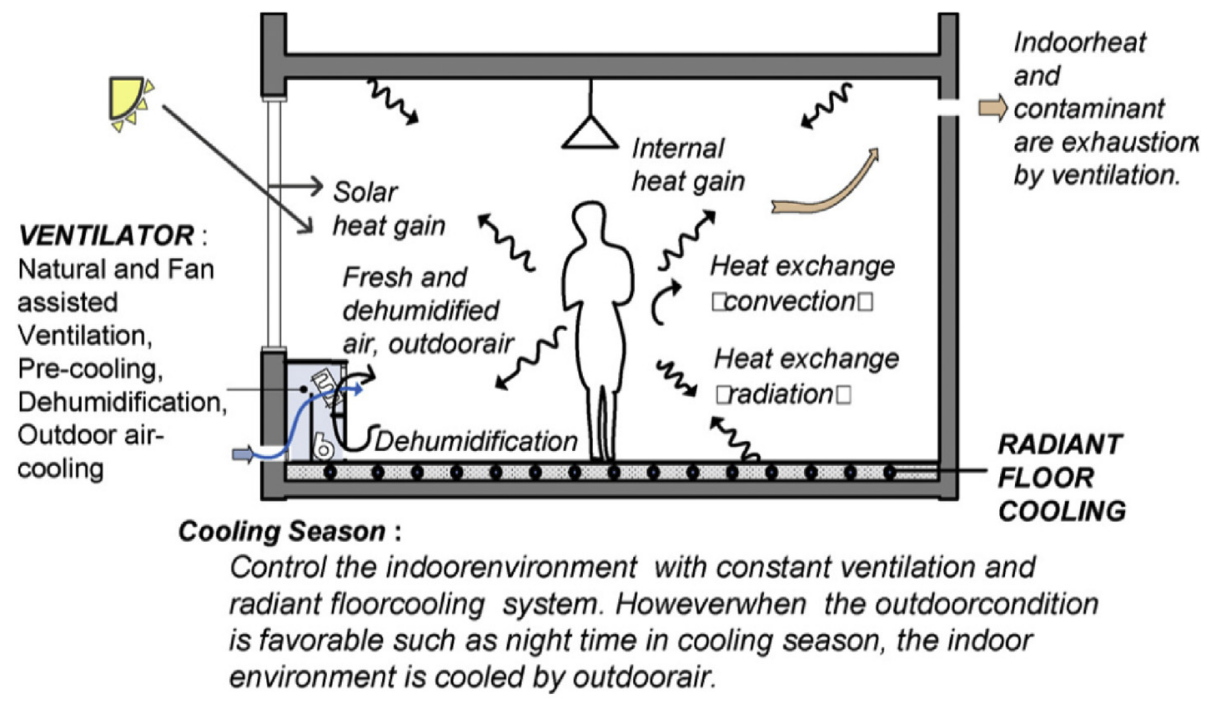

Fig. 13. Radiant floor cooling system coupled with dehumidification system [126]. 
It is clear that the numerous studies have established the fundamental theory of the RHC system and have demonstrated its feasibility for controlling the built environment in energy-efficient ways. Responding to the strengthened energy regulations or increased living standards, further studies as outlined below would be necessary to improve the system performance and to extend the application of the RHC system [43].

- Coupled simulation between dynamic energy simulation and computational fluid dynamics

- Integrated analysis of thermal-hydraulic interaction in multizone building equipped with hydronic RHC systems

- System design and control for the RHC system that serves both heating and cooling

- Implementation of the current advanced control strategies into multi-zone control

- Co-operative control of the RHC system and the building management system (BMS) (e.g. shade control for reducing solar heat gain, operable window control associated with condensation control, etc.)

- Practical and simplified technology for sensing radiant temperatures

- Optimization of hydronic network system in terms of pressure, flow rate and pumping energy

- Direct/indirect use of renewable energy as a heat production source

\section{Acknowledgement}

This work was supported by the National Research Foundation of Korea (NRF) grant funded by the Korea Government (MSIP) (No. 2016R1C1B2010955), and the Technology Innovation Program (10065684, Development of radiant heating and cooling system for reducing the green-house gases in building sector) of the Ministry of Trade, Industry \& Energy (MI, Korea).

\section{References}

[1] M. Yeo, I. Yang, K. Kim, Historical changes and recent energy saving potential of residential heating in Korea, Energy Build. 35 (2003) 715-727.

[2] R. Bean, B.W. Olesen, K. Kim, History of radiant heating \& cooling systems part 1, ASHRAE J. 52 (2010) 40-41.

[3] Z. Zhuang, Y. Li, B. Chen, J. Guo, Chinese kang as a domestic heating system in rural northern China - a review, Energy Build. 41 (2009) 111-119.

[4] R. Bean, B.W. Olesen, K. Kim, History of radiant heating \& cooling systems part 2, ASHRAE J. 52 (2010) 50-55.

[5] B.W. Olesen, Radiant floor heating in theory and practice, ASHRAE J. 44 (2002) 19-26.

[6] ASHRAE, ASHRAE Handbook-HVAC Systems and Equipment: American Society of Heating, Refrigerating, and Air Conditioning Engineers, 2016. Atlanta, GA.

[7] CIBSE, CIBSE Guide B-heating, Ventilating, Air Conditioning and Refrigeration: the Chartered Institution of Building Services Engineers, 2007. London.

[8] H.E. Feustel, C. Stetiu, Hydronic radiant cooling - preliminary assessment, Energy Build. 22 (1995) 193-205.

[9] J. Babiak, B.W. Olesen, D. Petras, Low Temperature Heating and High Temperature Cooling: REHVA GUIDEBOOK NO.7, Rehva, Brussels, 2009.

[10] ISO, ISO 11855-2:2012(E) Building Environment Design-Design, Dimensioning, Installation and Control of Embedded Radiant Heating and Cooling Systems. Part 2: Determination of the Design Heating and Cooling Capacity, International Organization for Standard, Genève, Switzerland, 2012.

[11] J. Feng, S. Schiavon, F. Bauman, Cooling load differences between radiant and air systems, Energy Build. 65 (2013) 310-321.

[12] ISO, ISO 11855-1:2012(E) Building Environment Design-Design, Dimensioning, Installation and Control of Embedded Radiant Heating and Cooling Systems. Part 1: Definition, Symbols, and Comfort Criteria, Internationa Organization for Standard, Genève, Switzerland, 2012.

[13] ISO, ISO 11855-4:2012(E) Building Environment Design-Design, Dimensioning, Installation and Control of Embedded Radiant Heating and Cooling Systems. Part 4: Dimensioning and Calculation of the Dynamic Heating an Cooling Capacity of Thermo Active Building Systems (TABS), Internationa Organization for Standard, Genève, Switzerland, 2012.

[14] ISO, ISO 11855-3:2012(E) Building Environment Design-Design,
Dimensioning, Installation and Control of Embedded Radiant Heating and Cooling Systems. Part 3: Design and Dimensioning, International Organization for Standard, Genève, Switzerland, 2012.

[15] ISO, ISO 11855-5:2012(E) Building Environment Design-Design, Dimensioning, Installation and Control of Embedded Radiant Heating and Cooling Systems. Part 5: Installation, International Organization for Standard, Genève, Switzerland, 2012.

[16] ISO, ISO 11855-6:2012(E) Building Environment Design-Design, Dimensioning, Installation and Control of Embedded Radiant Heating and Cooling Systems. Part 6: Control, International Organization for Standard, Genève, Switzerland, 2012.

[17] R. Li, T. Yoshidomi, R. Ooka, B.W. Olesen, Field evaluation of performance of radiant heating/cooling ceiling panel system, Energy Build. 86 (2015) 58-65.

[18] CEN, EN 1264-5 Water Based Surface Embedded Heating and Cooling Systems. Part 5: Heating and Cooling Surfaces Embedded in Floors, Ceilings and Walls - Determination of the Thermal Output, European Committee for Standardization, Brussels, Belgium, 2008.

[19] ISO, ISO/DIS 18566-1:2016 Building Environment Design - Design, Test Methods and Control of Hydronic Radiant Heating and Cooling Panel Systems - Part 1: Definition, Symbols, Technical Specifications and Requirements, International Organization for Standard, Genève, Switzerland, 2016.

[20] CEN, EN14240 Ventilation for Buildings - Chilled Ceilings - Testing and Rating, European Committee for Standardization, Brussels, Belgium, 2004.

[21] ASHRAE, ANSI/ASHRAE 138-2009: method of testing for rating ceiling panels for sensible heating and cooling, in: American Society of Heating, Refrigerating and Air Conditioning Engineers, Altanta, GA, 2009.

[22] F. Bockelman, S. Plesser, H. Soldaty, Advanced System Design and Operation of GEOTABS Buildings: REHVA GUIDEBOOK NO.20, Rehva, Brussels, 2013.

[23] K. Kim, B.W. Olesen, Radiant heating and cooling systems: part 2, ASHRAE J. 57 (2015) 28-37.

[24] T. Catalina, J. Virgone, F. Kuznik, Evaluation of thermal comfort using combined CFD and experimentation study in a test room equipped with a cooling ceiling, Build. Environ. 44 (2009) 1740-1750.

[25] Z. Tian, J.A. Love, A field study of occupant thermal comfort and thermal environments with radiant slab cooling, Build. Environ. 43 (2008) $1658-1670$.

[26] S. Corgnati, M. Perino, G. Fracastoro, P. Nielsen, Experimental and numerical analysis of air and radiant cooling systems in offices, Build. Environ. 44 (4) (2009) 801-806.

[27] X. Hao, G. Zhang, Y. Chen, S. Zou, D.J. Moschandreas, A combined system of chilled ceiling, displacement ventilation and desiccant dehumidification, Build. Environ. 42 (2007) 3298-3308.

[28] B. Lin, Z. Wang, H. Sun, Y. Zhu, Q. Ouyang, Evaluation and comparison of thermal comfort of convective and radiant heating terminals in office buildings, Build. Environ. 106 (2016) 91-102.

[29] ANSI/ASHRAE. Standard 55, Thermal Environmental Conditions for Human Occupancy, American Society of Heating, Refrigerating, and Air-Conditioning Engineers, Altanta, GA, 2010.

[30] ISO, ISO 7730: Ergonomics of the Thermal Environment-Analytical Determination and Interpretation of Thermal Comfort Using Calculation of the PMV and PPD Indices and Local Thermal Comfort Criteria, International Organization for Standardisation, Geneva, Switzerland, 2005.

[31] J. Lim, J. Jo, Y. Kim, M. Yeo, K. Kim, Application of the control methods for radiant floor cooling system in residential buildings, Build. Environ. 41 (2006) 60-73.

[32] G. Song, Buttock responses to contact with finishing materials over the ONDOL floor heating system in Korea, Energy Build. 37 (1) (2005) 65-75.

[33] B.W. Olesen, K.C. Parsons, Introduction to thermal comfort standards and to the proposed new version of EN ISO 7730, Energy Build. 34 (6) (2002) $537-548$.

[34] C. Stetiu, Energy and peak power savings potential of radiant cooling systems in US commercial buildings, Energy Build. 30 (1999) 127-138.

[35] W. Zeiler, G. Boxem, Effects of thermal activated building systems in schools on thermal comfort in winter, Build. Environ. 44 (2009) 2308-2317.

[36] J. Le Dreau, P. Heiselberg, Sensitivity analysis of the thermal performance of radiant and convective terminals for cooling buildings, Energy Build. 82 (2014) 482-491.

[37] G. Sastry, P. Rumsey, VAV vs. Radiant side-by-side comparison, ASHRAE J. 56 (5) (2014) 16-24.

[38] R. Machner, Thermal comfort in office buildings in line with a new German acoustic guideline, Energy Proc. 78 (2015) 2881-2886.

[39] N. Rage, O. Kazanci, B.W. Olesen. Numerical simulation of the effects of hanging sound absorbers on TABS cooling performance. In Clima 2016Proceedings of the 12th Rehva World Congress.

[40] L. Fang, G. Clausen, P.O. Fanger, Impact of temperature and humidity on the perception of indoor air quality, Indoor Air 8 (2) (1998) 80-90.

[41] M. Behne, Indoor air quality in rooms with cooled ceilings: mixing ventilation or rather displacement ventilation? Energy Build. 30 (1999) 155-166.

[42] F. Causone, F. Baldin, B.W. Olesen, S. Corgnati, Floor heating and cooling combined with displacement ventilation: possibilities and limitations, Energy Build. 42 (12) (2010) 2338-2352.

[43] K. Rhee, K. Kim, A 50 year review of basic and applied research in radiant heating and cooling systems for the built environment, Build. Environ. 91 (2015) 166-190. 
[44] K. Kim, B.W. Olesen, Radiant heating and cooling systems: part 1, ASHRAE J. 57 (2015) 28-37.

[45] M. Koschenz, V. Dorer, Interaction of an air system with concrete core conditioning, Energy Build. 30 (1999) 139-145.

[46] B. Lehmann, V. Dorer, M. Koschenz, Application range of thermally activated building systems tabs, Energy Build. 39 (2007) 593-598.

[47] M. Gwerder, B. Lehmann, J. Tödtli, V. Dorer, F. Renggli, Control of thermallyactivated building systems (TABS), Appl. Energy 85 (2008) 565-581.

[48] B.W. Olesen, M. de Carli, M. Scarpa, M. Koschenz, Dynamic evaluation of the cooling capacity of thermo-active building systems, ASHRAE Trans. 112 (1) (2006) 350-357.

[49] D.O. Rijksen, C.J. Wisse, A.W.M. van Schijndel, Reducing peak requirements for cooling by using thermally activated building systems, Energy Build. 42 (2010) 298-306.

[50] B.W. Olesen, K. Sommer, B. Düchting, Control of slab heating and cooling systems studied by dynamic computer simulations, ASHRAE Trans. 108 (2) (2000) 698-707.

[51] B.W. Olesen, Using building mass to heat and cool, ASHRAE J. 54 (2012) $44-52$.

[52] E.M. Saber, K.W. Tham, H. Leibundgut, A review of high temperature cooling systems in tropical buildings, Build. Environ. 96 (2016) 237-249.

[53] A.K. Athienitis, Investigation of thermal performance of a passive solar building with floor radiant heating, Sol. Energy 61 (1997) 337-345.

[54] J. Ren, L. Zhu, Y. Wang, C. Wang, W. Xiong, Very low temperature radiant heating/cooling indoor end system for efficient use of renewable energies, Sol. Energy 84 (2010) 1072-1083.

[55] S.J. Self, B.V. Reddy, M.A. Rosen, Geothermal heat pump systems: status review and comparison with other heating options, Appl. Energy 101 (2013) $341-348$.

[56] K. Daou, R. Wang, Z. Xia, Desiccant cooling air conditioning: a review, Renew. Sust. Energy Rev. 10 (2006) 55-77.

[57] X. Jin, X. Zhang, Y. Luo, R. Cao, Numerical simulation of radiant floor cooling system: the effects of thermal resistance of pipe and water velocity on the performance, Build. Environ. 45 (2010) 2545-2552.

[58] T. Yu, P. Heiselberg, B. Lei, M. Pomianowsk, Validation and modification of modeling thermally activated building systems (TABS) using EnergyPlus, Build. Simul. 7 (2014) 615-627.

[59] R.K. Strand, C.O. Pedersen, Implementation of a radiant heating and cooling model into an integrated building energy analysis program, ASHRAE Trans. 103 (1997) 949-958.

[60] D. Crawley, J. Hand, M. Kummert, B. Griffith, Contrasting the capabilities of building energy performance simulation programs, Build. Environ. 43 (4) (2008) 661-673.

[61] D. Crawley, L. Lawrie, F. Winkelmann, W. Buhl, Y. Huang, C. Pedersen, R. Strand, R. Liesen, D. Fisher, M. Witte, J. Glazer, EnergyPlus: creating a newgeneration building energy simulation program, Energy Build. 33 (4) (2011) 319-331.

[62] A. Laouadi, Development of a radiant heating and cooling model for building energy simulation software, Build. Environ. 39 (2004) 421-431.

[63] A. Wills, C. Cruickshank, I. Beausoleil-Morrison, Application of the ESP-r/ TRNSYS co-simulator to study solar heating with a single-house scale seasonal storage, Energy Proc. 30 (2012) 715-722.

[64] T. Weber, G. Jóhannesson, An optimized RC-network for thermally activated building components, Build. Environ. 40 (2005) 1-14.

[65] EQUA Simulation AB 2013. IDA Indoor Climate and Energy. Available: http:// www.equaonline.com/iceuser/pdf/ICE45eng.pdf/(Accessed February 2016).

[66] D. Xie, Y. Wang, H. Wang, S. Mo, M. Liao, Numerical analysis of temperature non-uniformity and cooling capacity for capillary ceiling radiant cooling panel, Renew. Energy 87 (2016) 1154-1161.

[67] J.A. Myhren, S. Holmberg, Flow patterns and thermal comfort in a room with panel, floor and wall heating, Energy Build. 40 (2008) 524-536.

[68] B. Ning, Y. Chen, H. Liu, S. Zhang, Cooling capacity improvement for a radiant ceiling panel with uniform surface temperature distribution, Build. Environ. 102 (2016) 64-72.

[69] M. Tye-Gingras, L. Gosselin, Comfort and energy consumption of hydronic heating radiant ceilings and walls based on CFD analysis, Build. Environ. 54 (2012) 1-13.

[70] T. Kim, S. Kato, S. Murakami, Indoor cooling/heating load analysis based on coupled simulation of convection, radiation and HVAC control, Build. Environ. 36 (2001) 901-908.

[71] S.J. Rees, P. Haves, An experimental study of air flow and temperature distribution in a room with displacement ventilation and a chilled ceiling, Build. Environ. 59 (2013) 358-368.

[72] J. Miriel, L. Serres, A. Trombe, Radiant ceiling panel heating-cooling systems: experimental and simulated study of the performances, thermal comfort and energy consumptions, Appl. Therm. Eng. 22 (2002) 1861-1873.

[73] F. Causone, S. Corgnati, M. Filippi, B.W. Olesen, Experimental evaluation of heat transfer coefficients between radiant ceiling and room, Energy Build. 41 (2009) 622-628.

[74] S. Okamoto, H. Kitora, H. Yamaguchi, T. Oka, A simplified calculation method for estimating heat flux from ceiling radiant panels, Energy Build. 42 (2010) 29-33.

[75] T. Cholewa, M. Rosiński, Z. Spik, M.R. Dudzińska, A. Siuta-Olcha, On the heat transfer coefficients between heated/cooled radiant floor and room, Energy Build. 66 (2013) 599-606.
[76] L. Zhang, X. Liu, Y. Jiang, Experimental evaluation of a suspended metal ceiling radiant panel with inclined fins, Energy Build. 62 (2013) 522-529.

[77] A. Koca, Z. Gemici, Y. Topacoglu, G. Cetin, R.C. Acet, B.B. Kanbur, Experimental investigation of heat transfer coefficients between hydronic radiant heated wall and room, Energy Build. 82 (2014) 211-221.

[78] D. Nall, Thermally active floors, ASHRAE J. 36 (1) (2013) 32-46.

[79] I. Doebber, M. Moore, M. Deru, Radiant slab cooling for retail, ASHRAE J. 52 (12) (2010) 28-38.

[80] J. Feng, G. Schiavon, F. Bauman, New method for the design of radiant floor cooling systems with solar radiation, Energy Build. 125 (2016) 9-18.

[81] J. Kreider, P. Curtiss, A. Rabl, Heating and Cooling of Buildings: Design for Efficiency, Rev. second ed., CRC Press/Taylor \& Francis, Boca Raton, 2012.

[82] ASHRAE, Chapter 18: Nonresidential Cooling and Heating Load Calculations, ASHRAE Handbook of Fundamentals, 2013. Atlanta, GA.

[83] F.C. McQuiston, J.D. Spitler, Cooling and Heating Load Calculation Manual, ASHRAE, Atlanta, GA, 1992

[84] J.D. Spitler, D.E. Fisher, C.O. Pedersen, The radiant time series cooling load calculation procedure, ASHRAE Trans. 103 (1997) 503-518.

[85] F. Bauman, J. Feng, S. Schiavon, Cooling load calculations for radiant systems: are they the same as traditional methods? ASHRAE J. 55 (12) (2013) 20-27.

[86] J. Niu, J. Kooi, H. Ree, Cooling load dynamics of rooms with cooled ceilings, Build. Serv. Eng. Res. Technol. 18 (4) (1997) 201-207.

[87] P. Simmonds, W. Gaw, S. Holst, S. Reuss, Using radiant cooled floors to condition large spaces and maintain comfort conditions, ASHRAE Trans. 106 (1) (2000) 695-701.

[88] B.W. Olesen, Radiant floor cooling systems, ASHRAE J. 50 (9) (2008) 16-22.

[89] F. Causone, S. Corgnati, M. Filippi, B.W. Olesen, Solar radiation and cooling load calculation for radiant systems: definition and evaluation of the direct solar load, Energy Build. 42 (2012) 305-314.

[90] M. De Carli, M. Tonon, Effect of modelling solar radiation on the cooling performance of radiant floors, Sol. Energy 85 (5) (2011) 689-712.

[91] N. Arcuri, R. Bruno, P. Bevilacqua, Influence of the optical and geometrical properties of indoor environments for the thermal performances of chilled ceilings, Energy Build. 88 (2015) 229-237.

[92] S. Ryu, J. Lim, M. Yeo, K. Kim, A study on the control methods for radiant floor heating and cooling system in residential building, ASRHAE Trans. 110 (2) (2004) 106-116.

[93] M. Shin, K. Rhee, S. Ryu, M. Yeo, K. Kim, Design of radiant floor heating pane in view of floor surface temperatures, Build. Environ. 92 (2015) 559-577.

[94] S. Cho, M. Zaheer-uddin, An experimental study of multiple parameter switching control for radiant floor heating systems, Energy 24 (1999) 433-444.

[95] K. Rhee, M. Yeo, K. Kim, Evaluation of the control performance of hydronic radiant heating systems based on the emulation using hardware-in-the-loop simulation, Build. Environ. 46 (10) (2011) 2012-2022.

[96] K. Rhee, S. Ryu, M. Yeo, K. Kim, Simulation study on hydronic balancing to improve individual room control for radiant floor heating system, Build. Ser. Eng. Res. Technol. 31 (1) (2010) 57-73.

[97] B.W. Olesen, Possibilities and limitations of radiant floor cooling, ASHRAE Trans. 103 (1) (1997) 42-48.

[98] B. Lehmann, V. Dorer, M. Gwerder, F. Renggli, J. Tödtli, Thermally activated building systems (TABS): energy efficiency as a function of control strategy, hydronic circuit topology and (cold) generation system, Appl. Energy 88 (2011) 180-191.

[99] A.K. De Wit, C.J. Wisse, Hydronic circuit topologies for thermally activated building systems - design questions and case study, Energy Build. 52 (2012) 56-67.

[100] J. Romaní, A. de Gracia, L.F. Cabeza, Simulation and control of thermally activated building systems (TABS), Energy Build. 127 (2016) 22-42.

[101] H. Karlsson, C. Hagentoft, Application of model based predictive control for water-based floor heating in low energy residential buildings, Build. Environ. 46 (2011) 556-569.

[102] T. Zakula, P. Armstrong, L. Norford, Advanced cooling technology with thermally activated building surfaces and model predictive control, Energy Build. 86 (2015) 640-650.

[103] J. Feng, F. Chuang, F. Borrelli, F. Bauman, Model predictive control of radiant slab systems with evaporative cooling sources, Energy Build. 87 (2014) 199-210.

[104] J. Lee, M. Yeo, K. Kim, Predictive control of the radiant floor heating system in apartment buildings, J. Asian Archit. Build. 1 (1) (2002) 105-112.

[105] T. Chen, Application of adaptive predictive control to a floor heating system with a large thermal lag, Energy Build. 34 (2002) 45-51.

[106] J.A. Candanedo, A.K. Athienitis, Predictive control of radiant floor heating and solar-source heat pump operation in a solar house, HVAC R. Res. 17 (3) (2011) 235-256

[107] G.P. Henze, R.H. Dodier, M. Krarti, Development of a predictive optimal controller for thermal energy storage systems, HVAC R. Res. 3 (1997) 233-264.

[108] A. Afram, F. Janabi-Sharifi, Theory and applications of HVAC control systems - a review of model predictive control (MPC), Build. Environ. 72 (2014) 343-355.

[109] L. Ferkl, S Jan. Ceiling radiant cooling: comparison of ARMAX and subspace identification modelling methods, Build. Environ. 45 (2010) 205-212.

[110] Y. Yu, V. Loftness, D. Yu, Multi-structural fast nonlinear model-based predictive control of a hydronic heating system, Build. Environ. 69 (2013) 
$131-148$.

[111] J. Široký, F. Oldewurtel, J. Cigler, S. Prívara, Experimental analysis of model predictive control for an energy efficient building heating system, Appl. Energy 88 (2011) 3079-3087.

[112] R. Zmeureanu, P. Fazio, Thermal performance of a hollow core concrete floor system for passive cooling, Build. Environ. 23 (1998) 243-252.

[113] E.M. Saber, R. Iyengar, M. Mast, F. Meggers, K.W. Tham, H. Leibundgut, Thermal comfort and IAQ analysis of a decentralized DOAS system coupled with radiant cooling for the tropics, Build. Environ. 82 (2014) 361-370.

[114] W. Chiang, C. Wang, J. Huang, Evaluation of cooling ceiling and mechanical ventilation systems on thermal comfort using CFD study in an office for subtropical region, Build. Environ. 48 (2012) 113-127.

[115] R.A. Memon, S. Chirarattananon, P. Vangtook, Thermal comfort assessment and application of radiant cooling: a case study, Build. Environ. 43 (2008) 1185-1196.

[116] K. Zhao, X. Liu, Y. Jiang, Application of radiant floor cooling in large space buildings - a review, Renew. Sust. Energy Rev. 55 (2016) 1083-1096.

[117] D. Song, T. Kim, S. Song, S. Hwang, S. Leigh, Performance evaluation of a radiant floor cooling system integrated with dehumidified ventilation, Appl. Therm. Eng. 28 (2008) 1299-1311.

[118] M. Kim, H. Leibundgut, A case study on feasible performance of a system combining an airbox convector with a radiant panel for tropical climates, Build. Environ. 82 (2014) 687-692.

[119] K. Zhao, X. Liu, Y. Jiang, Application of radiant floor cooling in a large open space building with high-intensity solar radiation, Energy Build. 66 (2013) 246-257.

[120] M.M. Hassan, Y. Beliveau, Modeling of an integrated solar system, Build. Environ. 43 (2008) 804-810.

[121] J. Lopez, F. Hernandez, F. Muñoz, A. Andres, The optimization of the operation of a solar desiccant air handling unit coupled with a radiant floor, Energy Build. 62 (2013) 427-435.

[122] L. Zhang, J. Niu, Indoor humidity behaviors associated with decoupled cooling in hot and humid climates, Build. Environ. 38 (2003) 99-107.

[123] M. Bruelisauer, K.W. Chen, R. Iyengar, H. Leibundgut, C. Li, M. Li, M. Mast, F. Meggers, C. Miller, D. Rossi, E.M. Saber, A. Schlueter, K.W. Tham, BubbleZERO-design, construction and operation of a transportable research laboratory for low exergy building system evaluation in the tropics, Energies 6 (2013) 4551-4571.

[124] M. Kim, H. Leibundgut, Advanced airbox cooling and dehumidification system connected with a chilled ceiling panel in series adapted to hot and humid climates, Energy Build. 85 (2014) 72-78.

[125] J. Niu, L. Zhang, H. Zuo, Energy savings potential of chilled-ceiling combined with desiccant cooling in hot and humid climates, Energy Build. 34 (2002) 487-495.
[126] J. Seo, D. Song, K. Lee, Possibility of coupling outdoor air cooling and radiant floor cooling under hot and humid climate conditions, Energy Build. 81 (2014) 219-226.

[127] A.S. Binghooth, Z.A. Zainal, Performance of desiccant dehumidification with hydronic radiant cooling system in hot humid climates, Energy Build. 51 (2012) 1-5.

[128] Z. Kang, X. Liu, J. Yi, On-site measured performance of a radiant floor cooling/ heating system in Xi'an Xianyang International Airport, Sol. Energy 108 (2014) 274-286.

[129] R. Hu, J. Niu, A review of the application of radiant cooling \& heating systems in Mainland China, Energy Build. 52 (2012) 11-19.

[130] K. Zhao, X. Liu, T. Zhang, Y. Jiang, Performance of temperature and humidity independent control air-conditioning system in an office building, Energy Build. 43 (8) (2012) 1895-1903.

[131] Y. Khan, V.R. Khare, J. Mathur, M. Bhandari, Performance evaluation of radiant cooling system integrated with air system under different operational strategies, Energy Build. 97 (2015) 118-128.

[132] N. Nutprasert, P. Chaiwiwatworakul, Radiant cooling with dehumidified air ventilation for thermal comfort in buildings in tropical climate, Energy Proc. 52 (2014) 250-259.

[133] A. Ameen, K. Mahmud, Desiccant dehumidification with hydronic radiant cooling system for air-conditioning applicants in humid tropical climates, ASHRAE Trans. 111 (2) (2005) 225-237.

[134] Y.H. Yau, S. Hasbi, Field analysis of indoor air quality in high rise and low rise green offices with radiant slab cooling systems in Malaysia, Indoor Built Environ. 24 (2) (2015) 174-184.

[135] W. Jin, L. Jia, Q. Wang, Z. Yu, Study on condensation features of radiant cooling ceiling, Proc. Eng. 121 (2015) 1682-1688.

[136] S.A. Mumma, Condensation issues with radiant cooling panels, ASHRAE IAQ Appl. (2001) 16-18.

[137] Uponor, Free-cooling Guide: Cooling Integration in Low-energy Houses, Uponor AB, IC/EL, Virsbo, Sweden, 2013.

[138] A. Novoselac, J. Srebric, A critical review on the performance and design of combined cooled ceiling and displacement ventilation systems, Energy Build. 34 (2002) 497-509.

[139] J. Jeong, S.A. Mumma, Practical cooling capacity estimation model for a suspended metal ceiling radiant cooling panel, Build. Environ. 42 (2007) 3176-3185.

[140] R. Kosonen, F. Tan, A feasibility study of a ventilated beam system in the hot and humid climate: a case-study approach, Build. Environ. 40 (2005) 1164-1173.

[141] E.M. Saber, K.W. Tham, H. Leibundgut, A review of high temperature cooling systems in tropical buildings, Build. Environ. 96 (2016) 237-249. 